The Catholic University of America, Columbus School of Law

CUA Law Scholarship Repository

1978

\title{
Significant Private Foundations and the Need for Public Selection of Their Trustees
}

David A. Lipton

The Catholic University of America, Columbus School of Law

Follow this and additional works at: https://scholarship.law.edu/scholar

Part of the Tax Law Commons

\section{Recommended Citation}

David A. Lipton, Significant Private Foundations and the Need for Public Selection of Their Trustees, 64 VA. L. REV. 779 (1978).

This Article is brought to you for free and open access by the Faculty Scholarship at CUA Law Scholarship Repository. It has been accepted for inclusion in Scholarly Articles and Other Contributions by an authorized administrator of CUA Law Scholarship Repository. For more information, please contact edinger@law.edu. 


\title{
VIRGINIA LAW REVIEW
}

VOLUME $64 \quad$ OCTOBER 1978

NUMBER 6

\section{SIGNIFICANT PRIVATE FOUNDATIONS AND THE NEED FOR PUBLIC SELECTION OF THEIR TRUSTEES}

\author{
David A. Lipton*
}

Every generation regards as natural the institutions to which it is accustomed.

R. TAWNEY, EQuaLtTy 91 (1964 ed.)

N February of 1965 , the United States Treasury Department
issued a Report on Private Foundations, ${ }^{1}$ investigating possible
improper activities of private foundations in their philanthropic
operations. The Report primarily discussed six areas in the opera-
tions of private foundations for which it recommended corrective
legislation..$^{2}$ Nearly five years later, after eleven months of consider-

* Assistant Professor of Law, Case Western Reserve University; on leave 1978-1979 for service with the Securities and Exchange Commission. The views expressed herein are those of the author and do not necessarily reflect the views of the SEC or of the author's colleagues on the staff of the SEC.

' U.S. Treasury Dep't, 89th Cong., 1st Sess., Treasury Dep't Report on Private Foundations (Comm. Print 1965) [hereinafter cited as Treasury Report]. The Department prepared the REPORT at the request of the Senate Committee on Finance and the House Committee on Ways and Means. The recommendations contained in the REPORT were presented again to Congress during the hearings on the Tax Reform Act of 1969, Pub. L. No. 91-172, 83 Stat. 487 (codified in scattered sections of 26, 42 U.S.C.). See StafF of HousE Comm. on Ways and Means \& Staff of Senate Comm. on Finance, 91st Cong., 1st Sess., Tax Reform Studies and Proposals, U.S. Treasury Dep't 26 (Comm. Print 1969) [hereinafter cited as Joint CoMm. REPORT].

2 Broadly, these discussions and recommendations dealt with the problems of (1) selfdealing between foundations and donors or related parties, (2) delays between the granting of deductions for specific contributions and the receipt of the benefit of these contributions by the public, (3) involvement of foundations in the operation and control of business enterprises resulting in competitive advantages and opportunities for subtle self-dealing, (4) control of business enterprises by donors or their families through ownership by a foundation of these enterprises, (5) financial transactions hy foundations that are unrelated to their charita- 
ation, Congress passed the Tax Reform Act of $1969 .{ }^{3}$ A substantial portion of this legislation dealt with private foundations and was designed to respond to the abuses highlighted in the 1965 Report. The Tax Reform Act of 1969 has been credited with successfully eliminating many of the abuses associated with private foundations. ${ }^{4}$ Indeed, the pertinent portions of the legislation focused on all the problems raised in the Treasury Report with one notable exception: the self-perpetuating influence and narrow base of representation of the governing bodies of foundations. ${ }^{5}$

While the Act has greatly curbed the potential for misconduct by private foundations, the basic operational system of the private foundation remains essentially unaltered. The structure of this system is at odds with several essential underlying values of our society. This system is devoid of any mandatory public input into a decisionmaking process that determines how the $\$ 30,000,000,000$ of foundations' assets and $\$ 2,000,000,000$ of annual distributions ${ }^{6}$ that

ble function, and (6) perpetual control of foundations by donors or their families and the corresponding lack of independent evaluation of a foundation's operations. See TrEasury REPORT, supra note 1, at 6-9, 15-57. The interest of the Treasury Department in investigating these problems arose from the favorable federal tax treatment provided private foundations as charitable institutions, which the Department viewed as serving to "encourage and, in substantial measure, finance private charity." Id. at 1.

3 Pub. L. No. 91-172, 83 Stat. 487 (codified in scattered sections of 26, 42 U.S.C.).

- In 1973, at the initiative of individuals such as John D. Rockefeller, III, Wilbur D. Mills, George P. Shultz, and William E. Simon, a privately funded commission was established to study philanthropy in the United States. The Commission on Private Philanthropy and Public Needs (commonly called the Filer Commission after its chairman, John H. Filer) has produced more than 70 original research papers dealing with philanthropy. The Commission's report was published in 1975. See Comm'n on Private Philanthropy and Public Needs, Giving IN AMERICA (1975) [hereinafter cited as FrLER CoMm'N REPORT]. The supporting papers for this report, written by scholars and experts in fields such as health, education, sociology, economics, and law, were published by the Department of the Treasury in 1977 in a five volume collection. Research Papers (U.S. Dep't of Treasury ed. 1977). This collection represents the most complete study ever made of charities and private foundations. One of the studies in this collection, prepared by the Council on Foundations, Inc., a nonprofit organization functioning as a trade association for foundations, concludes that "there is an informal consensus that [the Tax Reform Act of 1969] has in fact removed much of the potential for abuse" by foundations. Chairman and Staff, Council on Foundations, Inc., Private Foundations and the 1969 Tax Reform Act, in 3 Research PAPERS, supra at 1557, 1565.

s Some commentators have stated that lobbying by significant foundations ultimately defeated the legislation designed to deal with this problem. See text accompanying note 162 infra.

- These figures are aggregates for all foundations listed in Foundation CENTER, The FounDATION DIRECTORY (6th ed. 1977), plus those foundations not meeting the size requirements of the DIRECTORY but whose assets are estimatable from statistics given in the introduction to the DiRectory, id. at xi.

The figures for assets and grants used later in this article, see note 25 infra and accompanying text, include only "significant private foundations" and exclude community, company, 
have been dedicated to benefiting the public should be used. Typically, it provides for a self-appointing, self-perpetuating governing structure, often parochial in composition, that need not answer to any shareholder, customer, union member, or voter in managing the foundation. ${ }^{7}$ It allots to self-appointing trustees total discretion in administering wealth that has a vast impact upon society's ordering of its priorities in the areas of science, art, education, social policy, international development, and communications. Through tax deductions and exemptions, this system permits funds otherwise destined for the public treasury to accumulate instead as private foundations' wealth to be spent as determined by a nonpublicly selected management. The programs of this system are frequently under attack from groups across the political spectrum because of the lack of legitimacy of the governing structure that develops those programs. Finally, this system perhaps suffers from internal administrative inefficiencies caused by its very self-selecting nature.

Private foundations thus represent a unique instance in American society of an influential governing body that is neither selected by nor responsible to any constituency. ${ }^{8}$ To those concerned about the power of foundations and their lack of public input, these institutions are unfettered by the normal restraints of ownership or public responsibility in their control of assets. ${ }^{9}$ Even proponents of the

government, and the small private foundations not included in the DiRECTORY. See generally notes 14-29 infra and accompanying text.

7 To say that no mandatory public input into the governance of foundations exists is not to ignore state supervision of the trustees in carrying out their duties. This supervision, however, whether effective or otherwise, relates to patent abuses of position rather than dayto-day direction of the foundation. The lack of input with which this article is concerned centers on the ordinary regulation of foundations, not on extraordinary instances of abuse.

For discussion of supervision of foundations by instrumentalities of the state, see $M$. Fremont-Smith, Foundations and Government 194-408 (1965); Fremont-Smith, Duties and Powers of Charitable Fiduciaries: The Law of Trusts and The Correction of Abuses, 13 U.C.L.A. L. REv. 1041 (1966); Karst, The Efficiency of the Charitable Dollar: An Unfulfilled State Responsibility, 73 HaRv. L. Rev. 433 (1960); Office of Ohio Att'y Gen., The Status of State Regulation of Charitable Trusts, Foundations, and Solicitations, in 5 REsEARCH PAPERS, supra note 4, at 2705; Note, The Modern Philanthropic Foundation: $A$ Critique and a Proposal, 59 YALE L.J. 477, 483-85 (1950).

* In certain respects, the lack of control over the governing boards of private foundations can he likened to a similar lack of control over corporate management. See generally A. BRRLE \& G. Means, The Modern Corporation and Private Property 69-118 (1932). Whereas Berle and Means focused on the inability of the owners to effect control over the corporate entity, private foundations have no group of owners from which control has to be divorced. They have only a self-selected, nonaccountable controlling group that operates without restraint by or direction from any constituent body as long as it does not abuse its fiduciary duty. See generally notes 132-37 infra and accompanying text.

- See, e.g., Comm'n on Foundations and Private Philanthropy, Foundations, Private 
present structure of foundations admit, albeit approvingly, that they function similarly to "private "legislators." "10 Accordingly, the one area of abuse identified by the Treasury Report in 1965 but not dealt with by the Tax Reform Act of 1969-the inadequacies in the selection process of the governing bodies of private foundations-remains a serious concern today. ${ }^{11}$

The governing model customarily employed by private foundations is by no means necessary. One can find avenues to follow in establishing a governing board other than those leading to selfperpetuation and lack of public input. An extremely limited number of private foundations have established governing systems that guarantee a degree of public impact in the selection of trustees and that avoid the establishment of a "co-optive"12 governing board. Foundations other than private foundations utilize modes of governance readily transferable to private foundations that would enable them to avoid the limitations of the present co-optive system. Finally, alternative models for selecting governing officials employed in other institutional frameworks could be adapted to the private foundation. These other available forms of governance are explored as alternatives to the present system. ${ }^{13}$

To place these issues in proper perspective, this article first examines what constitutes a private foundation and then assesses its impact on social policy. After an exploration of the implications of the present tax treatment of foundations, this article turns to deficiencies in organizational structure and models of governance allowing for input by the public. These models are proposed because their operations conform more to the underlying values of society than do

\footnotetext{
Giving, and Public Policy 67 (1970) [hereinafter cited as Peterson Comm'n Report].

1 Mavity \& Ylvisaker, Private Philanthropy and Public Affairs, in 2 Research Papers, supra note 4 , at 795,798 .

II To be entirely accurate, it must be stated that the deficiencies that this article notes in the present governing structure of private foundations probably are more extensive than the deficiencies outlined in the TrEASURY REPORT, supra note 1, though they have similar themes. The TREASURY REPORT was concerned with the self-perpetuation of a donor's influence through self-selection of the board of trustees. See generally note 2 supra. This article focuses on that problem of self-perpetuation within the broader context of lack of public input in the selection process.

12 For a definition of the term "co-optive" as used in this context, see D. Young \& W. Moore, Trusteeship and the Management of Foundations 19 (1969) (current trustees choose their own successors).

${ }^{13}$ This article does not discuss the advantages of any of the alternative governing structures in terms of the grant programs or investment policies that might be developed under them. Such an evaluation ultimately rests on value judgments that vary greatly from person to person.
} 
foundations guided by self-selected officers. These values basically dictate that the public as a whole, not a self-appointed body of governors, should play the major role in determining what constitutes and best serves the common welfare. In addition, in the process of satisfying these external values, some demonstrable internal efficiencies accrue to foundations in terms of both the development of more vibrant and representative governing structures and the encouragement of a number of administrative efficiencies.

\section{What Is a Private Foundation?}

\section{A. Foundations in General}

Before discussing the impact of private foundations and how they are governed, a definition of the precise entity to be studied and an indication of the significance of what is included within and what is excluded from that definition are necessary. The most frequently cited definition of a foundation is that developed by F. Emerson Andrews, former director of and now consultant to the Foundation Center. ${ }^{14} \mathrm{He}$ defined a foundation as "a nongovernmental, nonprofit organization, having a principal fund of its own, managed by its own trustees or directors, and established to maintain or aid social, educational, charitable, religious, or other activities serving the common welfare."'15

The Andrews definition, either expressly or implicitly, captures the factors that distinguish foundations from other charitable organizations. First, any definition of foundations would have to include a reference to their purpose of serving the public welfare. Historically, this public purpose has been a major component in any description of a foundation. ${ }^{16}$ Second and equally important is the

14 The Foundation Center is a not-for-profit corporation chartered in 1956 and supported largely by foundations. It gathers and disseminates information on foundations. See Foundation Center, Annual Report-1976, at 5 (1977) (copy on file with the Virginia Law Review Association).

is F. Andrews, Philanthropic Foundations 11 (1956).

1" John Stuart Mill understood a foundation to be "money or money's worth (most commonly land) assigned, in perpetuity or for some long period, for a public purpose . . . ."J. MiLL, The Right and Wrong of State Interference with Corporation and Church Property, in 1 Dissertations and Discussions: Political, Philosophical, and Historical 26, 30 (1874) (emphasis added). A more recent commentator addressed himself to the public nature of foundations in explaining why he considered the term "private" to be an incorrect modifier of "foundations." Merrimon Cuninggim, former president of the Danforth Foundation, argued that foundation "funds are not private, for the money no longer belongs to the original donor, whoever he is. Rather, it is public money, set aside to be so by an uncommon act of stewardship on the part of the donor." M. Cuningam, Private Money and Public Service 4 (1972) (emphasis added). See generally pp. 795-802 infra. 
foundation's endowed status. Because private foundations own income-producing property, often donated by a single source, they are insulated from the burdens and restrictions of maintaining the degree of popular acceptability necessary to those organizations that regularly or periodically raise operating funds. ${ }^{17}$ As long as the foundation's securities and other properties produce adequate income, it can operate independently of any funding body free from "worry about the inpact of its activities on contributions."18 Furthermore, because a prudently invested endowment will produce a roughly predictable amount of income, foundations can promise and provide financial support to those entities they view as worthy of such encouragement.

A third essential element in the definition of a foundation is that it funds the activities of others. It is a grant-making institution rather than one operating its own charity or functioning as a "feeder" organization to support a specific charitable operation. This crucial aspect of its activities partially explains the influence of a foundation. It does not have to meet the exigencies of maintaining an individual school or hospital or research center. Rather, a foundation is free to do with its funds as it sees fit. ${ }^{19}$ Although foundations can and do make long-range commitments as to grants, they have no operating activities to sustain. Because they have no budgets to meet and no obligation to absorb inflationary operating costs, foundations are free to reduce grants during tight financial times. ${ }^{20}$ The foundation recognizes that fewer recipients will receive

17 An endowment is not an essential element of all definitions of foundations. The Peterson Commission did not include the requirement of an endowment in its definition. Instead, it categorized a charitable organization as a foundation as long as its sources of contributions were "relatively narrow," allowing it to he free from concern over the impact its activities have on contributions. PETERson CoMm'N RePort, supra note 9, at 40-41.

The Commission, chaired by Peter G. Peterson, was encouraged by John D. Rockefeller, III, and Alan Pifer, President of the Carnegie Corporation, funded by private, nonfoundation sources, and formed to study "all relevant matters bearing on foundations and private philanthropy." Id. at 3. Its report is one of the two or three most comprehensive recent studies of foundations and charitable organizations.

is Id. at 41.

1) This proposition is true so long as the purposes to which the funds are dedicated fall within the frequently broad confines of the foundation's charter or trust instrument. The potential breadth of these governing documents is aptly demonstrated by the articles of incorporation of the Ford Foundation, the largest private foundation. Article 2 reads: "The purpose or purposes of this corporation are as follows: A. To receive and administer funds for scientific, educational, and charitable purposes, all for the public welfare . . . ." Ford Foundation Art. of Incorporation art. 2 (1936) (emphasis in original) (copy on file with the Virginia Law Review Association).

20 For instance, the Ford Foundation in 1976 expended $\$ 150,900,000$ for programs, as op- 
as much as in the past; at the same time it understands that the foundation itself will continue in its role of determining which recipients are to receive what funds.

\section{B. Distinguishing Private Foundations}

Although the term "foundation" can include community foundations, governmental foundations, and corporation foundations as well as private foundations, the focus of this article is on the latter. Private foundations can be distinguished from the three other types both by funding source and by governing structure..$^{21}$

Community foundations, a variant first given form in 1914 in Cleveland, Ohio, ${ }^{22}$ are trusts designed to benefit a specific city or limited geographic area. They are governed by a broadly representative board and typically are funded by a larger group of donors than private foundations. A local banking institution generally manages the actual investments.

Governmental foundations are limited in number, being established and financed by the United States government. Among the best known is the National Science Foundation. Government officials select the governing boards of these foundations. Their operations are funded annually as part of the federal budget as opposed to a private foundation, the income of which is derived from a corpus.

Corporation foundations differ from private foundations in that they rarely have a significant endowment and more often function on current donations from a specific company. The board of trustees consists mainly or totally of officers and directors of the funding corporation. They often are a device for evening out corporate giving by distributing grants at a constant rate while receiving less from their corporate donor in a bad year and more in a good year.

posed to $\$ 195,200,000$ expended in 1975 , a reduction of nearly $25 \%$. See Ford Foundation, Annual Report 64 (1976) (copy on file with the Virginia Law Review Association). The Rebert Wood Johnson Foundation, the nation's second largest private foundation in terms of total assets, made grants totalling a little over $\$ 43,000,000$ in 1976 , as compared to $\$ 54,000,000$ in 1975. See Rebert Wood Johnson Foundation, Annual Report 39 (1976) (copy on file with the Virginia Law Review Association).

21 For more on the distinction between these types of foundations, see F. ANDREws, supra note 15, at 21-37; Petrrson Comm'n Report, supra note 9, at 47-53; A. Zurcher, ThB Management of American Foundations: Administration, Polictes and Social Role 17-29, 119-42 (1972) (the late Alfred Zurcher was the former executive director of the Alfred P. Sloan Foundation).

2 See Sugarman, Community Foundations, in 3 REsenRch PAPERS, supra note 4, at 1689, $1689-90$. 
Because of the manner in which these other-than-private foundations are funded and governed, this article has less concern with their operations. They do have constituencies to which they must answer, both in terms of future funding and present governance. Consequently, in this article they primarily serve as a source of comparison. ${ }^{23}$

\section{Significant Private Foundations}

The United States presently has about 26,000 private grantmaking and community foundations. Of these, eighty-five percent are small foundations with neither assets exceeding $\$ 1,000,000$ nor annual grants in excess of $\$ 100,000 .{ }^{24}$ Apart from these smaller foundations and the community and company foundations, roughly 2,300 foundations fall in the category of "significant" private foundations. Together, these 2,300 significant private foundations control nearly $\$ 26,000,000,000$ of assets and make annual grants totaling $\$ 1,500,000,000{ }^{25}$

The total assets of these significant private foundations exceed the individual assets of nearly all the top 500 American corporations ranked according to assets. ${ }^{26}$ As a group, private foundations hold about thirteen percent of corporate stock held by institutional

23 I.R.C. \$ 509 also draws a distinction between "private foundations" and all other foundations. Those organizations "excluded from the definition of 'private foundation' are generally those which either have broad public support or actively function in a supporting relationship to such organizations." Treas. Reg. $\S 1.509$ (a)-1 (1972). The exclusion provisions of $\S 509$ eliminate most corporation and community foundations and all governmental foundations from the definition of "private foundations." The term "private foundation" is refined further by I.R.C. $\$ 4942(j)(3)$, which distinguishes between "operating" and "nonoperating" foundations. Operating foundations are essentially those foundations that devote most of their earnings and assets directly to the conduct of a charitable activity, as distinguished from making grants to other charitable organizations that in turn conduct the activity. Thus the Code's counterpart to the term "private foundation" as used herein would be the "private, nonoperating foundation."

2s See Foundation Center, supra note 6, at ix-xxv.

${ }^{25} \mathrm{Id}$. at $\mathrm{xi}$. The $\$ 1,000,000$ of assets or $\$ 100,000$ of annual grants is an arbitrary cutoff used by the Foundation Center in determining which foundations are too small to be included in its directory. Id. This article adopts these criteria because the focus here is on foundations capable of having a significant impact on society. Accordingly, when the text refers to "foundations," it means these significant foundations unless otherwise noted.

* This comparison is based on the ranking of the top 500 American corporations appearing in The Forbes Assets 500, ForBes, May 15, 1977, at 165, 165-72. This listing was modified to exclude all banking corporations before making the comparison to private foundations. The two corporations of greater magnitude are AT\&T and Exxon. Among the corporations overshadowed by the total assets of all significant foundations are General Motors, Mobil Oil, and IBM. See id. at 165. 
stockholders (excluding family and individual trusts). ${ }^{27}$ Moreover, the actual magnitude of holdings of foundations probably is understated significantly. The Peterson Commission ${ }^{28}$ reported in 1970 that many foundations carried their assets at cost or some other basis rather than at market value. This led the commission to suggest that the estimate of foundations' assets prepared by the Foundation Center was probably low. ${ }^{29}$ The sheer size of these assets necessitates an inquiry into the impact of these institutions.

\section{The Impact of Significant Private Foundations}

\section{A. Breadth of Grants}

The grants that significant private foundations distribute each year equal more than double the annual budget of the United $\mathrm{Na}$ tions and exceed the individual budgets of two-fifths of the state governments in America. ${ }^{30}$ Since its inception, the Ford Foundation alone has distributed more than $\$ 4,960,000,000 .{ }^{31}$ Because these distributions often are intended to effectuate very broad and general purposes, a wide range of recipients both domestic and abroad feel the impact of the grants. The full range of fields in which foundations wield influence is hard to fathom. The Ford Foundation alone categorizes the grants it makes into fifty-eight different areas. ${ }^{32}$ Its 1976 annual report took fifty-seven pages merely to list and to describe briefly what organizations received the $\$ 156,700,000$ distributed in 1975.33 Three additional pages were devoted solely to listing "some" publications assisted by grants during the preceding year. ${ }^{34}$

Although the Ford Foundation is unique in that it has more than twice the assets of the next largest foundation, it is not unlike other private foundations in terms of the breadth of its influence. The Carnegie Corporation of New York, ranked tenth in terms of grants

" See R. Nelson, The Investment Policy of Foundations 6 (1967).

2x See generally note 17 supra.

2 Peterson Comm'n Report, supra note 9, at 49. For a recent confirmation that foundations still largely carry their assets at cost, see J. Traub, Accounting and RkPORTing Practices of Private Foundations 67 (1977).

30 Compare text accompanying note 25 supra with The World Almanac \& Book of Facts 78, 597 (1978).

"Weymouth, Foundation Woes, The Saga of Henry Ford II (pt. 2), N.Y. Times, Mar. 12, 1978, § 6 (Magazine), at 24.

32 The Ford Foundation distinguishes between eight broad fields of programs, which are further broken down into 58 subcategories. See Ford Foundation, supra note 20, at 1.

see id. at 2-58.

st See id. at 59-61. 
by the Foundation Center, ${ }^{35}$ appropriated $\$ 12,894,659$ for the year ending September 30, 1976, to forty-two educational institutions, sixty-seven other organizations, four internally administered projects, one fund for disseminating publications, and one fund for evaluating programs. ${ }^{36}$

The international as well as domestic influence of foundations is readily apparent. Although grants in the international sphere are made primarily by the larger foundations, such as Ford, Rockefeller, Kellogg, Carnegie, Lilly, and Clark, total giving by foundations to international activities approximates $\$ 200,000,000$ annually ${ }^{37}$

\section{B. Influence Through Decisions About Investments}

The economic impact of private foundations also arises from activities besides grants. Together, the significant private foundations control $\$ 26,000,000,000$ of invested assets. ${ }^{38}$ These assets provide foundations with influence, which can be exercised both in determining where to place an investment and in having potential clout with the business entity in which the investment is made.

Ironically, the influence of foundations is manifested primarily by not using their discretion as to where to place investments, which leads to a bifurcation between the goals of programs and the goals of investments. The Tax Reform Act of 1969 allowed foundations to make investments with socially oriented goals without fear of being penalized for carrying investments that would otherwise place their tax-exempt status in jeopardy. ${ }^{39}$ Nevertheless, one study, prepared

is Foundation Center, supra note 6, at xxi, tab. 7.

* See Carnegie Corp. of N.Y., Annual Report 21 (1976) (copy on file with the Virginia Law Review Association). The purpose of the Carnegie Corporation is stated as "the advancement and diffusion of knowledge and understanding," Carnegie Corp. of N.Y. Const. art. 2, § 1 (1911) (copy on file with the Virginia Law Review Association), which has been interpreted to mean that grants should be educational in nature but not limited to formal educational programs. See generally Carnegie Corp. of N.Y., supra at 22-24.

${ }^{7}$ Yarmolinsky, Philanthropic Activity in International Affairs, in 2 Research Papers, supra note 4 , at 761,762 .

3n See note 25 supra and accompanying text.

39 I.R.C. \& 4944 (a)(1) prescribes a tax of five percent of any amount invested by a private foundation that would jeopardize the foundation's carrying out any of its tax-exempt purposes. Treas. Reg. $\$ 53.4944-1(\mathrm{a})(2)$ (1972) provides that an investment jeopardizes a foundation's tax-exempt status if ordinary business care and prudence were not used in making the investment. Elements to be considered in determining the requisite duty of care for any investment include expected return, risk, and need for diversification. Id.

I.R.C. \& 4944(c), however, exempts from the above tax those investments the significant purpose of which is not production of income or appreciation of property but rather furthering the charitable purposes of the foundation. Examples cited in the regulations include loans at low interest rates to minority-owned businesses in deteriorated urban areas or to profitable 
in the early 1970's for the Ford Foundation, indicated that it could find no rush among foundations to establish such socially oriented investments. ${ }^{40}$ The explanation given in the report for the lack of overlap between investment goals (maximizing returns) and program goals (fulfilling the donor's purpose) is the foundation's motivation to maximize returns on investment and thereby maximize its ability to make grants." Another reason is that the portfolios of some foundations are so undiversified as to make social goals an unrealistic consideration in decisions about investments. ${ }^{42}$ Additionally, many foundations delegate the direction of investment strategy and the formulation of program goals to different staff members, which adds to difficulty in combining the two. ${ }^{43}$ Other foundations leave their investment policies to the discretion of a bank. ${ }^{44}$ Finally, unless excused from the duty by way of the trust instrument or statute, trustees of foundations have an obligation to invest the foundation's corpus in the manner that a "prudent man" would invest his own property. ${ }^{45}$ Although such proscriptions do not rule out program-related investments, they do discourage the more risky ones. ${ }^{46}$

However reasonable these justifications for the lack of overlap may be, the net result is that many foundations do not utilize their discretion as to investments to further specific social goals. A choice has been made, whether consciously or by default, to exclude from the services that foundations provide society those benefits generated by a socially oriented investment of $\$ 26,000,000,000$. Thus the impact that these foundations exert through their decisions to in-

businesses to induce them to establish operations in deteriorated urban areas, and interestfree loans to disadvantaged individuals to attend college. Treas. Reg. $\S 53.4944-3$ (b) (1972).

so B. Longstreth \& H. Rosenbloom, Corporate Social Responsibiltty and the InstituTIONAL INVESTOR 55 (1973). The authors noted:

There does not appear to be a widespread sense of urgency among foundations with regard to the social aspects of investment policy. One reason for this may be that foundations, although under Congressional scrutiny from time to time, are not subject to the constant pressures of a close, large, and vocal constituency.

Id. (emphasis added).

"Id. at 56. In one sense, the eventual expenditure of return on investments for grants reunites programs and investment. Overlap in this sense, however, does not have as much impact as an investment policy designed specifically to achieve program goals.

12 See id. at 55.

's See A. Zurcher, supra note 21 , at 100.

"See B. LONGSTRETH \& H. ROSENBLOOM, supra note 40 , at 55 .

s5 3 A. ScotT, The Law of Trusts $\$ 227.3$ (3d ed. 1967); 4 id. $\$ 389$.

" See ABA Comm. on Charitable Trusts, Investing Charitable Funds to Eliminate Poverty, 4 Real Prop., Prob. \& Trust J. 355 (1969). 
vest is in part a nonimpact, a nonuse of assets for program-related investments.

By contrast, some foundations have followed a course that leads to a degree of program-related investments by choosing to exercise their influence toward achieving social goals through investment policies. In 1968, the Ford Foundation decided to take social criteria into consideration in determining its investment strategy ${ }^{47}$ and thereafter began to extend its assistance in investments to many organizations otherwise ineligible for its grants because of their noncharitable status but eligible for its loans. The letter of gift that first funded the Russell Sage Foundation permitted trustees to set aside up to one quarter of the principal of the fund to make investments for "social betterment"; as to this proportion, the amount of return would be secondary. ${ }^{48}$

Reliance solely on such overt signs of investment strategy, however, necessarily underestimates the extent to which foundations implement social policies in their decisions about investment. Aside from a conscious, articulated strategy, other policies can have social impact. Princeton University, though not a grant-making foundation, was reported to have avoided making investments in certain major banks that were extending credit to the Republic of South Africa. ${ }^{49}$ Other foundations have avoided investments in the tobacco industry or in certain defense-related industries..$^{50}$ Whereas avoidance of investments might not rise to the level of a strategy, it certainly demonstrates the degree of influence that foundations can exert in making decisions about investments. These are all decisions made by the governing structures of private foundations without any requirement of external input as to how these decisions should be made, as long as the managers merely act prudently and satisfy the broad guidelines of the trust instrument.

${ }^{17}$ See W. Nielsen, The Big Foundations 95 (1972).

t* See R. Nelson, supra note 27, at 89.

19 See Simon, Foundations as Stockholders; Corporate Responsibility, in New York UNIversity: Proceedings of the Tenth Biennial Conference on Charitable Foundations 39, 44 (H. Sellin ed. 1971). Regardless of one's position on this particular investment policy, it could be admired for the simple fact that it was the outgrowth of a more democratic process than what typically characterizes grant-making foundations. The Princeton trustees responded to tbe demands of a specific constituency: the university students. Those with an affinity for certain democratic, or perhaps populist, ideals, which require that the managers of our resources be responsible to some public body, find a greater degree of legitimacy in a decisionmaking process through which the managers are compelled to react to the preferences of a specified community to whose benefit they are dedicated to serve-whether students, specific donees, or geographic segments of the population.

so See B. Longstreth \& H. ROSENBLOOM, supra note 40 , at 56 . 


\section{Influences as Shareholder}

Foundations have traditionally maintained a higher proportion of their assets in corporate stock than have most other institutional investors. ${ }^{51}$ This fact, in conjunction with the size of their holdings in assets, provides significant private foundations with a degree of influence upon many of the corporations in their portfolio. Unlike influence arising from discretion as to investment, a "nonuse" of the foundation's influence on the internal policies of portfolio corporations cannot occur. Both voting and not voting the shares constitutes an exercise of influence. A foundation's refusal to vote its portfolio stock might work to deny a corporation a quorum on any issue and prevent the management from effecting a specific fundamental change. Thus the mere act of voting, regardless of voting stance, provides corporate management an essential first step in the exercise of its power ${ }^{52}$ and gives the foundation some influence.

Beyond merely greasing the mechanism of corporate decisionmaking, the vote of private foundations has tended to lean heavily in favor of management. ${ }^{53}$ This practice need not necessarily reflect consideration of the issues involved. The SEC's seminal Institutional Investor Study ${ }^{54}$ revealed that fifty percent of the institutions surveyed had a policy of automatically voting for management. ${ }^{55}$ Management can rely on this voting block to provide a degree of certainty in obtaining any of its objectives regardless of the issue involved. Further, the SEC found that when financial institutions lose confidence in any particular portfolio corporation's management they sell their position rather than attempt to influence corporate decisions. ${ }^{56}$ This fact further skews the outcome of any vote in favor of management because institutional holdings in a specific corporation represent either a short term "yes" vote for management or, at worst, a long range "maybe" vote by a new shareholder

st See R. NeLson, supra note 27, at 7, chart 1. See generally SEC, INSTITUTIONAL INVESTOR Study REPoRT, H.R. Doc. No. 64, 92d Cong., 1st Sess. (1971) [hereinafter cited as INSTTUTIONAL INVESTOR STUDY]. In 1969 the foundations sampled by the SEC had 78.42\% of their assets invested in common stock and warrants. 3 id. at 1257 . This contrasts with the $17.3 \%$ of assets invested in common stock by financial institutions in general in 1968. 1 id. at 102.

32 See 5 Institutional INVESTOR StUdy, supra note 51, at 2749.

ss See R. Nelson, supra note 27, at 114.

st INSTITUTIONAL INVESTOR STUDY, supra note 51.

ss 5 id. at $2750-51$.

sc Id. at 2846. The SEC was referring to institutional investors in general, but no reason exists to believe that foundations behave differently. 
for management if the institution questions management's competence and chooses to sell. Of course, those foundations with substantial holdings in any corporation would be unable to dispose of their holdings except over an extended period of time. In these situations, the corporation's management could anticipate a safe block of affirmative votes in the long as well as the short run. ${ }^{57}$ As a result, the issue becomes not so much whether foundations customarily support the management of a company in their portfolio (although the predictability of that support increases the collective influence of foundations) but rather that foundations, by their very ownership of equity securities, possess a broad influence on corporate policy. This influence is attributable to the foundations' discretion in voting their portfolio securities and would be felt regardless of the direction of any particular vote..$^{58}$

Some might argue that this influence is lessened by certain legal

${ }^{57}$ Examples of foundations that could be considered solidly "locked in" to positions with particular companies in their portfolio include: the Sloan Foundation, with more than $\$ 89,000,000$ of $\mathrm{GM}$ common stock in a total portfolio of $\$ 297,000,000$ of marketable securities, Alfred P. Sloan Foundation, Report for 1976, at 62-63 (1976) (copy on file with the Virginia Law Review Association); the Lilly Endowment, Inc., which has $\$ 635,600,000$ of Eli Lilly \& Co. common stock in a total portfolio of $\$ 671,100,000$ in investments, Lilly Endowment, Inc., Report for 1976, at 88 (1976) (copy on file with the Virginia Law Review Association); the Mott Foundation, $\$ 145,500,000$ of whose $\$ 356,000,000$ of assets are tied up in GM common stock, Charles Stewart Mott Foundation, Annual Report for 1975, at 30 (1975) (copy on file with the Virginia Law Review Association). Even the relatively well diversified Mellon Foundation has more than $19 \%$ of its $\$ 219,000,000$ of investments in the form of Gulf Oil stock, Richard King Mellon Foundation, 1976 Annual Report 44, 45 (1976) (copy on file with the Virginia Law Review Association).

One of the best documented instances of foundations exerting their influence to support management in a shareholders' dispute occurred when the Project on Corporate Responsibility organized the Campaign to Make General Motors Responsible in 1970 and 1971. For an account of the issues involved in this proxy fight, see B. LONGSTRETH \& H. ROSENBLOOM, supra note 40; Schwartz, The Public-Interest Proxy Contest: Reflections on Campaign GM, 69 Mich. L. REv. 419 (1971). As events developed, the votes held by private foundations, even had they been voted against management, would not have altered the outcome of the proxy contest. Nevertheless, four of the largest foundations holding GM stock and assuming a promanagement stance-the Charles F. Kettering, Richard King Mellon, Charles Stewart Mott, and Alfred P. Sloan Foundations-were created by officers or directors of GM. See id. at $506 \mathrm{n} .435$. These four foundations together controlled more than two percent of all the votes cast in the proxy contest. In a corporation as widely held as GM, the vote of such a concentrated holding would be influential regardless of the outcome of the contest.

sx The law of trusts makes no demands as to which side a trustee must support. No reason exists why securities held by foundations need be voted for one particular position or another. A trustee of a foundation, like any otber trustee, can vote the trust portfolio in any manner that promotes the interests of the beneficiaries. $3 \mathrm{~A}$. ScorT, supra note $45, \S 193.1$. The law imposes no requirement that trustees assume that a corporation's management will have any sort of monopoly on the answer to the question of what will best benefit the shareholders. 
limitations on ownership of stock by private foundations. As previously mentioned, ${ }^{59}$ some of the provisions of the Tax Reform Act of 1969 relating to private foundations were enacted with an eye toward limiting the influence foundations can exert through their portfolio holdings. Ample reason can be found, however, to question the effectiveness of these restrictions. Generally, a foundation is permitted to own up to twenty percent of the voting stock of any single corporation without suffering a penalty tax. ${ }^{60}$ This figure is reduced by the percentage of such stock owned by any person with certain significant relations to the foundation, defined as a "disqualified person." 61 This portion of the Tax Reform Act of 1969 was intended to inhibit a then-increasing tendency to use private foundations as a means of perpetuating control over business entities. ${ }^{62}$

Even assuming that this general restriction would be an effective means of prohibiting control of corporations by foundations if strictly followed, it has been so diluted and qualified by myriad exceptions that it seldom will accomplish its intended objectives. To begin with, the twenty percent limit on a foundation's holdings in any corporation may be increased to thirty-five percent if the Treasury Department is satisfied that the corporation is controlled by one or more third parties unrelated to the foundation or any disqualified persons. ${ }^{63}$ Thus foundations are permitted to own thirtyfive percent of the shares in corporations controlled by unrelated third parties, and even if that does not amount to absolute control, it remains significant influence.

Moreover, the Tax Reform Act provides that if a foundation in existence on May 26, 1969, on that date owned, alone or with disqualified persons, more than twenty percent of any corporation, it need not reduce its holdings below the lesser of either the amount

"See notes 3-4 supra and accompanying text.

* I.R.C. $\S 4943(\mathrm{c})(2)(\mathrm{A})$.

" Disqualified persons include: substantial contributors to the foundation; foundation managers, which would include both trustees, officers, and certain employees of authority; any individual who owns more than $20 \%$ of a contributor to the foundation; certain relatives, including spouses, ancestors and lineal descendants, and spouses of lineal descendants; a business entity in which any one of the above individuals owns or holds a $35 \%$ interest; a private foundation controlled by the private foundation in question or receiving substantially all its contributions from the person or persons making contributions to the private foundation in question; or government officials. Id. $\S 4946(\mathrm{a})$.

12 See S. REP. No. 552, 91st Cong., 1st Sess. 27-31, reprinted in [1969] U.S. Code Cong. \& AD. NEws 2066, 2066-72.

B I.R.C. \& 4943(c)(2)(B). 
it so held or fifty percent of the voting stock for any one corporation to avoid a penalty tax. ${ }^{64}$ Consequently, any foundation that owned between twenty and fifty percent of the voting stock in any corporation as of May 1969 may continue to maintain those holdings indefinitely without incurring a penalty tax. Finally, should a foundation receive a new gift or bequest after 1969 that brings its total holdings in any corporation to more than twenty percent, it may take as long as five years to bring its holdings down to twenty percent without suffering a penalty tax ${ }^{65}$

Even positing an absolute twenty percent rule, serious doubt would remain as to whether owning twenty percent (or even less in a widely held corporation) would not constitute such significant influence as to be the functional equivalent of absolute control. When Representative Wright Patman spoke at the hearings before the House Committee on Ways and Means in support of the tax reform measures that ultimately evolved into the Tax Reform Act of 1969, he urged that the maximum ownership of a foundation in any corporation be set at three percent, not the twenty percent eventually adopted. ${ }^{66}$ Representative Patman, in proposing this figure, was not alone in believing that far less than twenty percent of a corporation's stock could give control. Although originally suggesting twenty percent as the cutoff figure, the Treasury Department asserted that as little as " 2,3 or 4 percent of the voting shares" of some large, publicly held corporations could constitute control. ${ }^{67}$ The SEC, in a slightly more conservative posture, thought ownership of ten percent of the outstanding stock would be sufficient to effect control or at least to influence significantly corporate decisionmaking. ${ }^{68}$ Regardless of which figure is the most accurate, far less than twenty percent ownership in a corporation can, in some instances, provide a shareholder with control. In many more in-

"Id. $\S 4943(\mathrm{c})(4)$. Should private foundations own more than $50 \%$ in any one corporation, they would then have 20,15 , or 10 years to reduce those holdings, depending upon the size of the holdings. Id. $\$ 4943$ (c)(4)(B).

ss Id. $\S 4943$ (c)(6).

4S See Tax Reform, 1969: Hearings Before the House Comm. on Ways and Means (pt. 1), 91st Cong., 1st Sess. 13 (1969) (statement of Rep. Patman).

a TREasury REPORT, supra note 1 , at 36 n.22.

* See 5 Instirutional Investor Study, supra note 51, at 2550. In one celebrated instance, In re Caplan's Petition, 20 A.D.2d 301, 246 N.Y.S.2d 913, aff'd, 14 N.Y.2d 679, 198 N.E.2d 908,249 N.Y.S.2d 877 (1964), ownership of three percent of the stock in a publicly held corporation was adequate to allow Roy Cohn to determine who would fill 7 of the 10 directorships on the company's board. 
stances such an interest constitutes a significant influence on corporate boards.

The Tax Reform Act of 1969 was not designed to restrict the influence of foundations on corporate decisions other than control situations. Nevertheless, not only did the Act consciously fail to address the issue of influence in noncontrol situations, but it also is quite ineffective in those contexts in which it did intend to restrict the influence of foundations.

\section{Interrelations with Portfolio Companies}

The sway that significant private foundations can exert on the policy of corporations in their portfolios is augmented by the interlocking of trustees of foundations and the boards of portfolio corporations. Without regard to the dominance of either party, directortrustee interlocking provides a means of intimate communication between a corporate board and a major shareholder. In conjunction with actual voting influence, this type of influence gives foundations direct input into corporate decisions, or alternatively it provides corporate management a voice within a body that must determine how to vote its shares in that corporation.

Although a realistic measurement of the effect of interlocking would be difficult, the SEC's study concluded that such relationships must increase the opportunity that already exists for foundations to exert influence as corporate shareholders. ${ }^{69}$ Of the foundations surveyed by the SEC, none had a policy forbidding trustees from holding a similar position on the board of portfolio companies. ${ }^{70}$ The phenomenon of interlocking is widespread among the significant private foundations. In fact, of the twenty largest foundations listed by size of assets, eighteen have one or more trustees also sitting as a director on the board of a portfolio corporation, and one foundation (Pew Memorial Fund) does not list individual trustees, leaving only one foundation with no interrelationships. ${ }^{71}$

\section{Special Tax Treatment}

Part of the illogic of significant private foundations being in a

"See 5 Institutional Investor StUdy, supra note 51, at 2716.

7* Id. at 2731, tab. IV-26.

"Sources for this study included Foundation Center, supra note 6; Standard \& Poor's Register of Corporations, Directors and Executives (1977); Who's Who in America (1976); and either the 1976 annual report of the foundation involved or its 1976 IRS Form 990 -PF or Form 990-AR. 
position to exert, without public input, the influence attendant to their investments and grants is that foundations possess some of their vast wealth by virtue of public subsidization. The public gives up tax revenues both in allowing a charitable deduction for the foundation's donors ${ }^{72}$ and in exempting the private foundation itself from income taxation. ${ }^{73}$ In a very real sense, at least half of the wealth now possessed by private foundations represents a sacrifice by the general public, through deductions and exemptions, of otherwise collectable federal tax funds. ${ }^{74}$

One could argue that a reason for exempting private foundations from the payment of federal income tax is the difficulty in determining what really constitutes taxable income to a charitable institution. ${ }^{75}$ Regardless of the legitimacy of this difficulty, the fact re-

72 See note 81 infra.

${ }^{23}$ I.R.C. $\$ 501(a)$ applies the exemption to certain "exempt organizations," defined in $\S 501$ (c) to include "foundation[s], organized and operated exclusively for religious, charitable, scientific, testing for public safety, literary, or educational purposes." Id. $\S 501$ (c)(3). The exemption has numerous qualifications. Foundations lose their exemption if they devote a "substantial" part of their activities to political activities. Id. Taxes also may be imposed upon the unrelated business income of exempt foundations. Id. \$ 511. Further, the 1969 Tax Reform Act imposes a number of penalty taxes on private foundations for: defined acts of self-dealing, id. $\S 4941$; failure to pay out annually a specified percentage of asset value (presently, at least five percent), id. $\$ 4942(\mathrm{e})$; maintaining ownership greater than $20 \%$ in portfolio companies, id. $\S 4943$, see text accompanying notes $63-64$ supra; purchasing risky investments, I.R.C. $\S 4944$; and making certain disfavored expenditures such as expenditures for carrying on propaganda, influencing public elections, or making grants to organizations without responsibility for expenditures, $i d$. $\$ 4945$. These qualifications apply largely to unusual situations; the basic rule grants an exemption to foundations that comply with the general requirements for exempt status.

"This is an estimate devised by Professor Karst based on the assumption of the average tax bracket of people who donate to private foundations. See Karst, The Tax Exemption of Donor-Controlled Foundations, 25 OHIo ST. L.J. 183, 187 (1964). Were one to consider the benefit to foundations derived from their exemptions from various state taxes as well, this figure might seem conservative.

${ }^{75}$ Professors Bittker and Rahdert argued that were the exemption removed, computing the "net income" of exempt organizations "would be a conceptually difficult, if not a selfcontradictory task." Bittker \& Rahdert, The Exemption of Nonprofit Organizations from Federal Income Taxation, 85 YALE L.J. 299, 307 (1976). Initially, they argued, we would be confronted with the question of whether gifts and bequests would be excluded from income. Id. at 308-09. This question is not of great concern to foundations because after their formative years they operate largely out of interest on endowments. The authors also were concerned with what could be justified as legitimate business deductions because neither the expenses of a foundation nor its actual grants can be characterized as expenses incurred to generate profits. Id. at 309-13. In the past, these questions have been mooted by the fact that an exemption has and does exist, see text accompanying note 94 infra, and no need has arisen to calculate the taxable income of foundations.

The answers to these questions are of some relevance, however, if the tax exemption is part of the subsidization provided to foundations. Suffice it to say that the questions posed are 
mains that foundations at present are not responsible for paying any income taxes on their earnings, unlike a business entity, trust, or private individual. In 1973, the staff of the Senate Subcommittee on Foundations estimated that foundations annually avoid paying over $\$ 600,000,000$ in taxes. ${ }^{76}$ Because this exemption allows foundations to retain funds that they otherwise would have to pay into the public treasury, it is essentially a means of disbursing federal funds to foundations.

This fact is not diminished by the excise tax of four percent private foundations have paid on their net income from investments since $1970 .{ }^{77}$ This tax is not intended as a tax on income per se but rather as a means of compensating the government for services provided to foundations and offsetting the costs of audits by the Internal Revenue Service. ${ }^{78}$ Although this tax may exceed what is neces-

not insolvable. Unless one were willing to say that foundations do not earn any taxable income by the very nature of their function (which perhaps begs the issue of the impact of the exemption), then the exemption does have some meaning and does provide a benefit. No reason exists to believe that, as with individuals, trusts, and corporations, tax principles could not be devised to provide meaningful measurements of taxable income of charities were the tax exemptions not available. With the development of these principles one could measure the full impact of the exemption. Until then, one can only say that the exemption provides some degree of federal subsidy, and one can only make gross estimates of the amount of that subsidy.

7 Senator Vance Hartke referred to a $\$ 610,000,000$ tax exemption for 1972 in the hearings before bis subcommittee in 1973. See Hearings on the Role of Private Foundations in Today's Society and a Review of the Impact of Charitable Provisions of the Tax Reform Act of 1969 on the Support and Operation of Private Foundations Before the Subcomm. on Foundations of the Senate Comm. on Finance, 93d Cong., 1st Sess. 24 (1973) (statement of Sen. Hartke).

${ }^{77}$ I.R.C. $\S 4940$ (a). The "net investment income" is equal to the foundation's interest, dividends, rents, and royalties (except tbat proportion taxable as unrelated business income under $i d$. $\S 511$ ) plus capital gains and less ordinary or necessary expenses paid or incurred in managing the income-producing assets. Id. $\$ 4940$ (c).

${ }^{78}$ The House version of the 1969 Tax Reform Act spoke of the tax on investment income as a device for ensuring that the costs of the "benefits of government" would be "borne, at least to some extent, by all of those able to pay." The tax was viewed as a "user fee" to compensate the government for its "vigorous and extensive administration." The House fixed its tax at 7.5\% of income. H.R. REP. No. 413, 91st Cong., 1st Sess. 4, reprinted in [1969] U.S. Code Cong. \& AD. News 1645, 1648. The Senate, on the other hand, called the tax an "audit fee tax," stating that it was not in any way withdrawing the income tax exemption and making clear that the tax was solely a "user charge" to pay for the supervision of private foundations. It set the tax at .2\% of the assets. S. REP. No. 552, 91st Cong., 1st Sess. 27, reprinted in [1969] U.S. CODE CONG. \& AD. News 2027, 2032. The conference report supported neither the House nor the Senate but labelled the tax an "excise tax" and set the tax at $4 \%$ of income. CoNF. REP. No. 782, 91st Cong., 1st Sess. 278, reprinted in [1969] U.S. CodE Cong. \& AD. News 2392, 2392. Professors Bittker and Rahdert pointed out that, assuming annual income of private foundations to be roughly $5 \%$ of assets, the $4 \%$ excise tax closely approximates the Senate's proposal. Bittker \& Rahdert, supra note 75, at 326 n.68. The regulations also refer to the tax as an "excise tax" and not an "income tax." See, e.g., Treas. Reg. § 53.4940-1(a) (1977). 
sary to offset the costs of audits, ${ }^{79}$ in view of the negligible amount of revenue it raises ${ }^{80}$ it certainly is not a serious inroad on the taxexempt status of foundations. For all practical purposes, the tax exemption for private foundations remains intact.

Of greater significance to private foundations than their exemption, but intimately linked to it, are the various charitable deductions available to donors. In terms of both the ultimate monetary benefit to foundations and the total tax revenue lost by the federal government, the provisions of the Internal Revenue Code granting charitable deductions are far more important than the provisions granting exemptions. An individual taxpayer is allowed a deduction from his gross income for contributions to tax-exempt foundations. ${ }^{81}$ Interestingly, the Code treats nonoperating, private foundations differently from both operating foundations and publicly supported foundations. Deductions are allowed for contributions to nonoperating, private foundations only to the extent of twenty percent of the taxpayer's contribution base for the year, whereas the deductible figure is fifty percent when the recipient is an operating or publicly supported foundation or private foundation that distributes all contributions received within a year of receipt. ${ }^{22}$ The difference in treatment of nonoperating foundations reflects a desire to give greater

7see Bittker \& Rahdert, supra note 75, at 326; Wadsworth, Private Foundations and the T'ax Reform Act of 1969, 39 Law \& ConTEmp. ProB. 255, 259 (1975); Worthy, The Tax Reform Act of 1969: Consequences For Private Foundations, 39 LAw \& Contemp. Prob. 232, 247 (1975).

xn This tax raised only a little more than $\$ 76,600,000$ in fiscal year 1974 . See Worthy, supra note 79 , at 247 .

"I I.R.C. $\$ 170$ (a)(1) (granting the deduction for charitable contributions). The Code defines a charitable contribution as a gift to or for the use of

[a] corporation, trust, or community chest, fund or foundation:

(A) created or organized in the United States or in any possession thereof, or under the law of the United States, any State, the District of Columbia, or any possession of the United States;

(B) organized and operated exclusively for religious, charitable, scientific, literary, or educational purposes, or to foster national or international amateur sports competition (but only if no part of its activities involve the provision of athletic facilities or equipment), or for the prevention of cruelty to children or animals;

(C) no part of the net earnings of which inures to the benefit of any private shareholder or individual; and

(D) which is not disqualified for tax exemption under section 501 (c)(3) by reason of attempting to influence legislation, and which does not participate in, or intervene in (including the publishing or distributing of statements), any political campaign on behalf of any candidate for public office.

Id. $\$ 170(\mathrm{c})(2)$.

${ }^{x} I d . \$ \$ 170(\mathrm{~b})(1)(\mathrm{A}),(\mathrm{D})$. For a discussion of the Code's classification of foundations, see note 23 supra. 
encouragement to organizations that immediately spend their revenues for the activities they support and are not mere intermediaries that later will distribute donations to "operating" charities. ${ }^{83}$ Framing the distinction in terms of percentage of contribution base also favors the foundation that is, by necessity, more responsive to public pressures and priorities because it must rely on continuous giving rather than on contributions by a donor. ${ }^{84}$

Each of these charitable deductions constitutes a federal subsidy to foundations. In each instance, the government does not collect federal taxes on assets going to or for the use of private foundations. Donors are thus giving to foundations what they otherwise would have to surrender to the federal treasury. The charitable deduction traditionally has been justified on the ground that charitable contributions do not represent consumable income. ${ }^{85}$ Many challenge this view and regard charitable giving as another form of consumption with the donor purchasing either status, a feeling of having done a charitable deed, or perpetuation of his own values. Therefore, they argue, it should be subject to taxation just like any other outlay of income. ${ }^{86}$

The budget of the United States government recognizes that the concept underlying charitable tax deductions and tax exemptions for foundations represents a form of government funding of these institutions. Since 1976, the budget has included a "tax expenditure" analysis designed to account for losses in federal revenue attributable to deductions and exemptions intended to achieve certain social and economic ends. ${ }^{87}$ Of course, defining a tax provision as an "expenditure" requires the determination of a "normal" tax structure from which the particular provision is regarded as a deviation. ${ }^{87}$ Inasmuch as deductions for charitable contributions are con-

\footnotetext{
* See H.R. REP. No. 749, 88th Cong., 1st Sess. 53 (1963).

" $*$ "Besides a deduction from the donor's income tax, the Code provides a similar deduction in computing the donor's gift and estate taxes. See I.R.C. $\$ \S 2055,2522$. With gift and estate taxes, however, the Code has no limiting differential between nonoperating, private foundations and other types of foundations.

* See Wallace \& Fisher, The Charitable Deduction Under Section 170 of the Internal Revenue Code, in 4 RESEARCh PAPERS, supra note 4, at 2131, 2132.

* See Frter Comm'N REPort, supra note 4, at 107. See also McDaniel, Study of Federal Matching Grants for Charitable Contributions, in 4 Research PaPERs, supra note 4, at 2417, 2500-03.

* This tax expenditure section in the budget is required as of 1976 by $\S 601$ of the Congressional Budget Act of 1974, 31 U.S.C. \& 11(e) (1976).

xx Although such a normal tax structure is nowhere defined in the Internal Revenue Code, certain features, such as progressive tax rates for individuals, threshold levels for tax liability, personal exemptions, deduction of business expenses, exclusion of unrealized capital gains
} 
sidered deviations from this norm, they necessarily are tax expenditures. ${ }^{89}$ The government has estimated that the tax expenditure attributable to the deductions for charitable contributions will be $\$ 6,000,000,000$ in $1978 .{ }^{90}$ This does not readily reveal what the federal tax expenditure might be for private foundations alone because the figure includes tax expenditures for all deductions for charitable contributions except those made to educational institutions. Moreover, it does not include a separate accounting in terms of tax expenditure for the exemption afforded foundations.9. The figure does indicate, however, that the expenditure can be estimated and that the Treasury Department considers providing the deduction as equivalent to providing federal funding.

Admittedly, determining the "standard" tax involves normative judgments. ${ }^{92}$ That does not alter the basic premise of the notion of the tax expenditure, which is that certain tax policies result in the flow of federal funds to certain activities just as if federal funds were

and losses, and treatment of individuals and corporations as separate tax-paying entities are considered part of the normal tax structure.

* See generally Office of Management \& Budget, Special ANalyses Budget of the United States Government, Fiscal Year 1978, at 119-42 (1978) [hereinafter cited as Special Analyses]; Office of Management \& Budget, The Budget of the United States GovernMENT, Fiscal YeAR 1978, at 34-38 (1978).

- Special Analyses, supra note 89, at 130, tab. F-2.

"1 The special analysis of the budget does not indicate why the figure representing tax expenditure for charities does not include the tax exemption afforded qualifying charities. The analysis of tax expenditures in the budget, however, is not intended to be all-inclusive. The government has acknowledged that some items are not contained because they have not been fully studied or because insufficient information exists upon which to base an estimate Id. at 124. Because no determination has been made as to what would constitute taxable income for an otherwise exempt charity, see note 75 supra, measurement of the benefit of the exemption in terms of a tax expenditure would be hard. Many commentators have recognized that the exemption in essence serves as a subsidy. See, e.g., Reiling, Federal Taxation: What is a Charitable Organization?, 44 A.B.A.J. 525, 595 (1958).

"2 Some tax scholars argue that providing an accounting for tax expenditures is difficult, if not impossible, because of the judgmental factor involved in determining an "ideal or correct tax structure." See Bittker, Accounting for Federal "Tax Subsidies" in the National Budget, 22 NaT'L TAX J. 244, 248 (1969). The federal budget, which for three years has been able to provide a consistent accounting of tax expenditures and a rational scheme for the inclusion and exclusion of various items, is the hest response to such critics. Cf. Surrey \& Hellmuth, The Tax Expenditure Budget-Response to Professor Bittker, 22 Nat'L TAX J. 528,533 (1969) (a large group of tax experts agree precisely on what could be considered a working model for a tax norm). But see Bittker, The Tax Expenditure Budget-a Reply to Professors Surrey \& Hellmuth, 22 NAT'L TAX J. 538 (1969). Furthermore, one easily can find convincing and respected literature arguing that the existence of a tax norm is axiomatic and that a departure from that norm in the form of exemptions and deductions constitutes a subsidy. See S. Surrey, Pathways to Tax Reform 1-14 (1973); Surrey, Federal Income Tax Reform: The Varied Approaches Necessary to Replace Tax Expenditures with Direct Governmental Assistance, 84 HaRv. L. REv. 352, 352-64, 381-94 (1970). 
being distributed to these activities. The debate will continue as to whether some tax policies should be classified as the "norm" or "special"; refinements must continue to be made. Nevertheless, for federal budgetary purposes, charitable deductions for gifts to private foundations, and arguably the exemption for these foundations, represent the equivalent of a flow of federal funds to private foundations.

One response to this is to attach great siguificance to the historical extension of exemptions to charitable organizations. Some commentators have viewed the historical record as establishing acceptance of the proposition that taxing foundations is not necessarily a privilege of government and that it should not be regarded as part of the normal tax structure. ${ }^{93}$ Yet this argument suggests more than one conclusion. A tradition of exempting foundations from income taxation as well as permitting deductions for donations supports the observation that whatever policies or values operate in the present to encourage the federal subsidization of foundations also operated at earlier times. Special tax treatment for charitable organizations has been a component of the American tax system practically since its inception, having antecedents in the British system of the seventeenth century. ${ }^{94}$ Explanations for this special treatment have varied. As to the exemption, many saw the imposition of an "income" tax as being hard to reconcile with the activities of nonprofit organizations..$^{95}$ Moreover, the extensive recordkeeping associated with the tax, in some instances, was thought to be overly burdensome in light of the minimal production of revenue..$^{96}$ As to the deduction, an individual's contributions to a charity were not considered a portion of that individual's consumable income. ${ }^{97}$ Also, both the exemption and the deduction were considered means of supporting charities without direct governmental funding..$^{98}$

${ }^{3}$ See, e.g., J. Nason, Trustres and THE Future of Foundations 9-11 (1977) (study undertaken at the request of the Council on Foundations and funded by 11 foundations). Nason, a member of several private foundations, states:

Congress has from time to time expanded or contracted the charitable deduction; but that does not change the fact that exemption from taxation, while it may be limited by government, is not an act of grace on the government's part, but a recognition of a right not to be taxed except as the result of specific popular action.

Id. at 9 (footnote omitted).

" See Bittker \& Rahdert, supra note 75, at 301; Rabin, Charitable Trusts and Charitable Deductions, 41 N.Y.U.L. REv. 912 (1966); Reiling, supra note 91, at 527.

*s See Bittker \& Rahdert, supra note 75, at 302, 304.

N See id. at 304.

"See Rabin, supra note 94, at 915.

* See Bittker \& Rahdert, supra note 75, at 304 n.14. 
To say that this special tax treatment amounts to a federal subsidy does not deny the legitimate motivations underlying the deduction and exemption, nor does it argue for the repeal of either. Nor does it imply that charities, particularly private foundations, are not providing a service that otherwise would have to be provided by government. It does mean that government is assisting private foundations in providing these services and that these private foundations are spending public funds as the governing boards of private foundations see fit. The trustees who invest and disburse these funds do so as servants of the public (the beneficiary of the foundations), but the public has no part in determining the selection of its "servants" nor in advising its "servants" how these funds can best benefit the public.

Furthermore, the benefits provided to private foundations by the charitable deduction might well go beyond the immediate subsidy involved in allowing funds that otherwise would be channeled to the treasury to flow into foundations. Studies conducted for the Filer Commission indicated that for each $\$ 1$ lost by the treasury due to the charitable deduction, charitable organizations actually receive between $\$ 1.15$ and $\$ 1.29$ in additional contributions over and above what they would receive without the deduction..$^{99}$ If the results of these studies are correct, ${ }^{100}$ then private foundations benefit not merely by the amount of the lost tax revenue but also by an additional sum surpassing the taxpayer's actual benefit in tax savings. Thus the tax benefit to charities would exceed the subsidy that can be identified as a tax expenditure.

\section{The Present Governing Structure of Significant Private Foundations}

As the discussion so far has shown, significant private foundations have enormous social and political impact. Their special treatment by the tax laws, which in effect means they wield such influence in part through use of public funds, accentuates their unique nature. Given the notion of responsiveness to the public-an idea fundamental to our society-one might assume the public has its say in

" FILER Comm'N Report, supra note 4, at 129. See generally Feldstein \& Clotfelter, Tax Incentives and Charitable Contributions in the United States: A Microeconometric Analysis, in 3 RESEARCH PAPERs, supra note 4, at 1393.

100 Several earlier studies had indicated that the revenue foregone by the treasury actually exceeded the benefit of the contributions to charities. See, e.g., McDaniel, supra note 86, at 2435-42. 
the governance of these institutions. This assumption is inaccurate, as is shown by an examination of the process used to select the trustees and the way in which those trustees exercise their power once selected.

Private foundations usually take the form of either a charitable trust, a not-for-profit corporation in which the corporate directors are viewed as the trustees, or a trust that is instructed to form a notfor-profit corporation. ${ }^{101}$ The corporation is the most popular form for structuring the private foundation. Foundations can be established by a document such as a trust agreement between the donor and trustee, by a will, or even by an oral statement of trust. Additionally, filing of the corporate charter and bylaws in a state may be required in the case of the not-for-profit corporation. In practice, little difference can be found between the powers and duties of the directors of a not-for-profit corporation and the trustees of a charitable trust. ${ }^{102}$

\section{A. Selection of Trustees}

\section{Homogeneity and Its Consequences}

The initial members of any foundation's governing body we could construct, whether serving as directors or actual trustees, would be selected by the donor. The pool of potential trustees is generally limited to persons with whom the donor has had personal contacts and in whom he has confidence. Often the original board will be composed of family members, close business associates, and legal or financial advisors. ${ }^{103}$ The donor predictably seeks trustees with values common to his own to ensure both the advancement of his objectives and the smooth functioning of the board. One study of foundations with assets of $\$ 100,000,000$ or more conducted for the Twentieth Century Fund summarized its findings as to the selection process with respect to the initial board:

$[\mathrm{M}]$ embers of a foundation board are normally drawn from the business, legal, financial, and social circles of the donor and his

\footnotetext{
ia See generally F. ANDrews, Legal Instruments of Foundations (1958); F. ANDREws, supra note 15, at 38-62; M. FremonT-SMITH, supra note 7, at 54-111; H. OLECK, Non-ProfiT Corporations, Organizations and Associations (3d ed. 1974); A. Zurcher, supra note 21, at 10; Note, supra note 7 , at $480-81$.

102 See M. FrEmont-Smith, supra note 7, at 154-57.

103 See F. ANDREWS, supra note 15, at 64-65; J. NASON, supra note 93, at 47-48; W. NiELSEN, supra note 47, at 314-15. Foundations whose initial boards were chosen from personal relations of the founder include the Carnegie, Ford, Rockefeller, and Sage Foundations. See F. ANDREws, supra note 15, at 65 .
} 
family since they can be counted on to have "sound" ideas and not to make trouble. The usual product of this selection method is a homogeneous group consisting of aging members of the upper socioeconomic class in American society. ${ }^{104}$

While the homogeneity of the original board would tend to dissipate over time if the successors were selected in a process independent of the influence of the private foundation, such is not the case. Reelection of the initial trustee is the rule for the typical foundation unless the trustee does not desire to be reelected. ${ }^{105}$ When replacements must be made, the trustees themselves generally make the selection. ${ }^{106}$ Suggestions for replacements usually come from among the board members, with deciding weight occasionally accorded to the preference of the retiring trustee.$^{107}$ Because social diversity is not of particular concern in selecting replacements, the unsurprising result is that "a relatively homogeneous group of trustees will generally select new members at least of their own social status, if not better." 108 A very recent examination of trustees of foundations, in

104 W. NiELSEN, supra note 47 , at 315 .

us See F. ANDREws, supra note 15 , at 81 .

${ }_{106}$ Two examples of provisions in the governing documents of significant private foundations demonstrate the typical manner in which the donor provides for replacement of trustees. The indenture establishing the Duke Endowment, a foundation operating as a trust and one of the 10 largest private foundations, provides:

Vacancies occurring among the trustees from any cause whatever (for which purpose an increase in the number of trustees shall be deemed to cause vacancies to the extent of such increase in number of trustees) may be filled by the remaining trustees at any meeting of the trustees, and must be so filled within six months after the vacancy occurs ....

Indenture Establishing Duke Foundation art. 2 (Dec. 11, 1924) (copy on file with the Virginia Law Review Association). Similarly, the constitution of the Carnegie Corp. of New York, a foundation operating as a not-for-profit corporation, as amended reads:

Section 2. The board of trustees shall be constituted as follows:

The number of trustees shall be seventeen. Sixteen seats shall be known as term seats and one seat as an ex officio seat. The ex officio seat shall be occupied by the person who is the president of Carnegie Corporation of New York. The holders of the term seats shall be elected by the remaining trustees of the corporation to serve for terms of four years or such lesser period as may be specified at the time of election. The duration of terms shall be so scheduled that the number of seats to be filled shall, so far as practicable, be equal in each succeeding year.

Section 4. Any vacancy in the board of trustees may be filled for the unexpired term by the votes of a majority of the remaining trustees.

Carnegie Corp. of N.Y. Const. art. 1, $\$ 2,4$ (Nov. 10, 1911) (copy on file with the Virginia Law Review Association). Thus provisions for replacement of trustees vary little with the form a foundation takes.

${ }^{107}$ See D. Young \& W. Moore, supra note 12, at 19.

${ }^{\mathrm{n} n \mathrm{x}}$ Id. 
commenting on the tendency of boards to select people like themselves as successors (much as the donor seeks to find a reflection of his own personality in the original board), noted: "The selfperpetuating character of most boards makes it natural for trustees to select people of their own ilk, i.e., people of comparable standing in the community, people who will think alike rather than creating controversy by introducing different and possibly conflicting viewpoints."109

Regardless of the board's performance or its policies (provided they remain within the generally broad dictates of the founding instruments), it will select its replacements. Failure to achieve a board's own or anyone else's goals raises no bar to self-perpetuation. Nor, for that matter, does anyone exist to measure the foundation's performance. Win or lose, the board determines its successors, and its successors will more likely than not mirror the personality of the predecessors. Once set in motion, this governing structure continues in an uninterrupted line of succession much as would a monarchy. Unlike the management of a corporation or a union, or even a university that occasionally must respond to pressures from alumni or students, the board of a foundation is not vulnerable to having its choices of candidates for reelection or replacement overridden. This results in an almost incomparable degree of "sameness." "An overwhelming majority of the trustees of the large foundations are white, Anglo-Saxon and Protestant," concluded the Peterson Commission in 1970.110 The Commission reported after examining twenty-five of the largest foundations that

only four of these foundations have boards whose members might be considered broadly representative of the nation's various geographic regions. The remainder tend to represent only single regions with the New England-Middle Atlantic regions in the clear lead. Moreover, half of the trustees of the twenty-five largest foundations attended Ivy League colleges, and roughly two-thirds have business, banking, or legal backgrounds. Of the foundation trustees for whom information was available, none had a background in organized labor. There were very few Catholics, Jews, or Negroes, or, for that matter, women or young trustees. ${ }^{111}$

\footnotetext{
ion J. Nason, supra note 93, at 41.

"Ho Peterson Comm'N Report, supra note 9, at 89-90.

iII Id. at 89 . One commentator reproduced the following quote verbatim from a 1936 sociological examination of trustees, which he concluded "remains all too true":

[The typical trustee's] position in the community is that of a person who belongs to the highest income-receiving class of the population; he is, presumably, "respectable"
} 
Regardless of how attractive or unattractive this type of personality might be, such uniformity necessarily has three consequences. First, the trustees are limited in their ability to identify and respond to the problems of a broad spectrum of society. Second, certain administrative inefficiencies develop that further limit the foundation's ability to deal with pressing issues. Third, conflicts of interest arise, a factor deleterious to any organization.

As to the first phenomenon, the Filer Commission noted a need for foundations to "broaden their boards and staffs so that a wide range of viewpoints is reflected in each organization's very governance and management." 112 In fact, every major study of foundations within the last ten years, although often sponsored by the foundations themselves, has found a need to broaden the personality of the typical board of trustees so that foundations can better perform their obligations to the public. ${ }^{113}$

The homogeneity of the trustees also is reflected in the types of administrative structures they have set up to carry out their task. Many of the significant private foundations have not developed the kind of staff that is necessary to identify public interests and administer the foundation's funds accordingly. One study conducted in 1972 found that of the thirty-three largest foundations, "[o]nly ten

and "conventional" and belongs to the "best" clubs and churches, and he associates with men of prestige, power and affluence. His training has been largely in the arts and humanities and he possesses only a slight background in the sciences and technologies. He resides in the Northeastern section of the United States and has attended one of the private colleges in that region. His "intelligence" is ranked high by various institutions of higher learning from whom he has received signal honors. He receives his income primarily from profits and fees. In short, he is a member of that successful and conservative class which came into prominence during the latter part of the nineteenth and early twentieth centuries, the class whose status is based primarily upon pecuniary success.

J. Nason, supra note 93, at 40 (quoting E. Lindeman, Wealth and Culture 44-46 (1936)). See W. NIELSEN, supra note 47 , at 316 .

112 Filer Comm's Report, supra note 4, at 170-71.

"13 E.g., id. at 170-72. See J. NASON, supra note 93 , at 39-45; W. NiELSEN, supra note 47 , at 313-22; Peterson Comm'n Report, supra note 9, at 89-90; A. Pifgr, The Foundation in the YEAR 2000 (1968) (monograph published by the Foundation Center Library and authored by the president of the Carnegie Corp. of N.Y.); A. ZURCHER, supra note 21, at 35-37; Donee Group, Private Philanthropy: Vital and Innovative or Passive and Irrelevant, in 1 Research PAPERS, supra note 4, at 49,66 (an appraisal of Fn,ER COMM'N REPORT, supra note 4, by a group of public interest personnel and charity representatives).

The Peterson Commission found that the lack of diversity in trustees restricted the foundation's vision of society. "The implication of [the Peterson Commission] study is simply this: these boards clearly lack the kind of diversity that could further enlarge their perceptions about the raw surge of American life . . . PETErson Comm'n REPORT, supra note 9, at 90. 
have reasonably well-developed and capable staffs."114 Without adequate staffing, a foundation has a difficult time discerning the needs of individual applicants, verifying the validity of those applicants' projects, and developing priorities for committing the foundation's resources. Introducing a degree of public participation into the process for selecting trustees, however, might cause boards to strive on their own to remedy any administrative inefficiencies. To the extent that a public process of selection would instill in trustees a sense of public accountability, those foundations presently lacking an administrative framework that permits goals and priorities to be established by a board and administered through the foundation's staff might be motivated to develop one.

Another outgrowth of the co-optive nature of the selection process is the kind of potential conflict of interest that arises when foundation trustees sit on the boards of portfolio corporations. ${ }^{115}$ Most large foundations were originally funded with shares of the corporation in which the donor made his wealth. Both the original board and its successors are staffed by business associates who occupy positions in the management of the primary corporation in the portfolio-the donor's corporation. The boards are also staffed with descendants of the donor, who also will have a financial interest in the donor's corporation. Of the thirty-three largest private foundations studied by Nielsen, only four were found not to have significant donorfamily or corporate ties. ${ }^{116}$ Another study of conflicts of interest in foundations indicated that of the ten largest foundations, six have more than half their money invested in one company, and each of those foundations constitutes those six companies' largest single shareholder. ${ }^{17}$ This intertwining of the foundation's and the corporation's personnel can lead trustees of the foundation to ignore the foundation's interest to preserve the tie between the donor's corporation and the donor's foundation.

11 W. NIRLSEN, supra note 47, at 323. See A. ZURCHER, supra note 21, at 47-48 (citing a 1972 study of 662 foundations conducted by the author, which found that " 32 foundations with assets between 25 and 100 million dollars, six foundations with assets between 100 million and 300 million dollars, and one foundation with assets between 300 million and 1 billion dollars" had no paid staff). Cf. Peterson Comm'N REport, supra note 9, at 249, tab. A. 38 (using a different sample base than Zurcher with somewhat different results though with the same implication).

IIs See text accompanying notes 69-71 supra.

iI See W. NierSEN, supra note 47, at 280.

17 See C. Welles, Confucts of Interrest: Non-Profit Institutions 63 (1977). 
The most flagrant example of trustees favoring their own interests over those of the foundation is, of course, the failure of one-stock foundations to diversify. It is no coincidence that at virtually every foundation that keeps most of its assets in the shares of a single company, the board of trustees is closely linked to the company. Willingness to permit such a concentration of assets runs directly counter to long-accepted standards of prudent investment management. ${ }^{118}$

The model that has been adopted for most significant private foundations as a process for selecting their governing members is inadequate not merely from an external viewpoint (which demonstrates that those for whom the foundations exist have no control over those who direct these foundations) but also from an internal focus (which shows that the co-optive process of selection is deleterious to the creative functioning of foundations).

\section{Chances for Heterogeneity in the Present System}

The almost complete homogeneity of boards of foundations is a predictable outcome of a process marked by self-selecting trustees. While a problem in itself for its obviously deleterious effects on the vitality of foundations, ${ }^{119}$ it is equally a telltale indicator of the total absence of input by the public in the selection of trustees. One inmediate response to arguunents suggesting broadening representativeness of trustees is that even if homogeneity among boards leads to limitations in the outlook of foundations, diversity can be achieved without inandatory public input. The Filer Commission took this position in strongly urging that any diversity be created internally rather than be imposed externally. ${ }^{120}$

This position has a number of weaknesses, the inost significant of which is the apparent lack of initiative among foundations to move toward diversification. In addition, unless the selection model is altered, any internally created diversity will in itself be a co-opted diversity. Governance by self-selecting trustees almost by definition

118 Id. at 69.

11. See notes 112-18 supra and accompanying text.

120 FILer Comm'N REPorT, supra note 4, at 171. The Commission seemed to regard exact representativeness as the only means by which public input can be had in the process of selecting trustees. It disregarded intermediate means of achieving some expression of public choice that do not involve perfect representation. It thus rejected any public control of the selection process. Other ways can be thought of, however, to bring the public, or representatives of the public, into the selection process without requiring a duplication of our present governmental structure. See pp. 821-32 infra. 
leads to a certain degree of isolation of governing boards from the external interests of society in spite of any self-created diversity. Henry Ford, II, the last family member to sit on the board of trustees of the Ford Foundation, resigned in early 1977 after serving for thirty-three years as a trustee. Referring to his fellow trustees, who are considered to make up one of the more diverse governing boards, ${ }^{121}$ he stated that he had sensed among them a trend toward closing themselves off from "outside influences." He admonished the trustees: "All wisdom does not repose at [Ford Foundation headquarters] . . . . We have a lot to learn from many sources. We shouldn't tolerate a fortress mentality." 122 The question remains whether a "fortress mentality" ever can be avoided within a selfperpetuating governing body.

In one respect, to speak of the homogeneity of boards is a bogus concern. While this lack of diversity is indicative of the lack of public input in the process of selecting trustees, the inverse of that proposition would not hold. Heterogeneity on foundation boards, as the boards are now structured, would not be indicative of public participation in the selection of the trustees. Even though women and minority groups might be beginning to have a presence on the boards of significant private foundations, ${ }^{123}$ it is because foundations are choosing their own "diverse" successors, not because the public has been brought in on this decision. The nineteen percent of board members who are women no more represent the public's choices for trustees of foundations than do the eighty-one percent who are men.'These female trustees, like their male counterparts, were chosen by a co-optive process totally internal to the foundation. While such diversification must be considered a movement in the right direction, as long as the model for the governing structure of

121 See note 123 infra.

122 N.Y. Times, Jan. 12, 1977, \& B, at 6, col. 6.

12 Some indications have appeared that diversity among trustees of foundations is beginning to increase. Nason reports that "a slowly increasing number of foundations, including some of the middle-sized family foundations and particularly some of the leaders hike Ford, Rockefeller, and Carnegie, have made conscious efforts to broaden and diversify their board membership by adding women, blacks and individuals chosen from non-power segments of society." J. NASON, supra note 93 , at 41 . The FoundATION NEwS reported results of a survey taken in 1976 indicating that women now comprise $19 \%$ of trustees of foundations. Oliver, Women in Foundations Are Challenging the Status Quo, Foundation News, July-Aug. 1976, at 28, 30. A study conducted by the Association of Black Foundation Executives, Inc., based on limited returns of its survey, found the ratio of blacks on foundation boards with $\$ 25,000,000$ to $\$ 100,000,000$ in assets to be 1 in 24 . Hearn, Foundation Trustees: The Need For Diversity, Foundation News, Nov.-Dec. 1974, at 11, 12. 
foundations utilizes co-option as its mode of succession, diversity in itself cannot reflect public influence on choice of trustees. Although these matters cannot be measured, one would suspect, based solely on the process of selection, that any diversity of appearance on present boards does not extend to spirit or outlook.

Even if a self-selection process could guarantee that the boards of large foundations would display true diversity in composition, a disturbing reality would remain. The public, which is to be benefited by these foundations and by the diversity created on their boards, would have no input in selecting those who constitute the boards and who determine what will benefit the public and how the benefits shall be administered.

\section{B. Exercise of Power by Trustees}

An examination of the exercise of power by trustees once they are selected reveals two disturbing facts. First, the board usually has nearly unfettered discretion as to the policies of the foundation. Second, despite this power, some boards have abdicated their decisionmaking to the foundation's staff, a fact that makes reform in terms of public input even more difficult. The authority of the board of trustees typically extends broadly to cover the essential policy and operational issues that comprise areas of fiscal investment and distribution of grants. ${ }^{124}$ Because the purposes of the foundation's existence often are left open by indefinite references to "scientific, educational and charitable purposes,"125 the powers of the trustees also include the authority to determine the scope and nature of the foundation's operations.

Foundations are not self-contained institutions that will follow a predetermined course of investment and grant-distribution. To the contrary, most foundations can follow many divergent paths on any number of issues, and the consequences each path holds for the

\footnotetext{
124 For example, the bylaws of the Ford Foundation dictate that "all corporate powers shall be exercised by and under the authority of the hoard of directors." Ford Foundation Bylaws art: $2, \S 2$ (April 1975) (copy on file with the Virginia Law Review Association). The Carnegie Corporation's constitution indicates that the "property of this corporation shall be held, and its affairs shall be managed and controlled, by a board of trustees not to exceed seventeen in number." Carnegie Corp. of N.Y. Const. art. 1, \&1 (Dec. 16; 1976) (copy on file with the Virginia Law Review Association).

125 See note 19 supra. With some foundations, the role of the trustee is more limited because the foundation's purpose is more closely defined. An example is the Longwood Foundation, established in 1937, the primary purpose of which is to support and operate a horticultural garden in Kennett Square, Pennsylvania. See W. Niersen, supra note 47, at 141.
} 
society being served by the foundation differ vastly. In spite of this, the trustees alone decide which path to follow. A few illustrations of major changes in the policies of a foundation brought about internally by specific boards show the importance of this aspect of present governing structures:

Example 1: In 1977 the trustees of the Rockefeller Brothers Fund decided to give away almost half of the foundation's $\$ 209,000,000$ in assets to twenty-five causes and institutions supported by the Rockefeller brothers. The program represented a major policy change, as grants previously had been awarded mostly from earned incoine. The change was adopted in recognition of a desire of the surviving Rockefeller brothers to provide for their special causes before control of the fund, which was established in 1940, passed on to their children. ${ }^{126}$ As with all major private foundations, the public for whose benefit this foundation was established did not play a role in selecting the trustees who made this decision.

Example 2: The Ford Foundation, determining that a higher return could be had in equities than in the nore secure bonds of which it had significant holdings, reduced its holdings in bonds from $35 \%$ of its portfolio in 1967 to $11 \%$ in 1972, leaving itself highly vulnerable to large portfolio losses in the bear stock market of 19731974. As a consequence of this investinent policy, in conjunction with inflation and a policy of overspending, the foundation today has less than half the purchasing power it had ten years earlier. ${ }^{127}$

Example 3: As a whole, foundations in the decade of 1957 to 1967 made a substantial shift in some broad areas of giving. The proportion of funds in that period going to international activities increased froin $8 \%$ of total giving to $21 \%$. Giving to the humanities rose froin $4 \%$ to $18 \%{ }^{128}$ While these aggregate fignres represent giving by all foundations, it is safe to conclude that most, if not all, of the grant-1naking decisions involved in determining these priorities were not inade by the public or by publicly selected individuals.

None of these exainples should be regarded as surprising because they inerely confirm the obvious: the trustees of foundations yearly must make crucial decisions that determine how inillions, if not billions, of dollars will be spent to benefit the public. They also

i26 See N.Y. Times, June 23, 1977, \& B, at 1, col. 1.

127 See Weymouth, supra note 31 , at 22, col. 1, 84, col. 1-2, 86, col. 1 .

123 Bolman, The Effect of Government Grants on Foundations, in New YORK UNIVERSITY: Procegdings of the Eighth Biennial Confrrence on Charitable Foundations 15, 16-17 (H. Sellin ed. 1967). 
make decisions as to how foundations' funds are to be invested. These issues are not self-resolving. They directly affect and are intended to benefit the public, yet the public does not partake in their resolution.

The problem is exacerbated when the board defers to one particular board member or abdicates its responsibility to the foundation's staff. Studies have found organizational breakdowns in the lack of influence of some boards on the foundation's policy. The Peterson Commission observed that, depending on how the foundations characterized their own operations, "in nearly two-fifths of the foundations, board members play so small a role in foundation grantmaking as to border on the invisible. A donor or another single individual dominates many of these foundations." 129 Commentators have alleged that some boards are controlled by their staffs. ${ }^{130}$ In those situations, the trustees selected to determine and serve the public interest are not in a position to fulfill their responsibilities.

Lack of guidance by boards creates difficulties in terms of reforming the present system. The board's nonexercise of its authority would work to short circuit the impact of any public involvement in the selection process and should be examined further in selecting a means to effect public input in the governance of foundations. If public input in the governing of foundations is to exist, it can be employed most effectively at the level of selecting the trustees because the trustees are the ones who make the important decisions for the foundation. Once trustees become accountable to the public they could be expected to reassert their proper authority over policy.

\section{Why the Need for Public Selection of Trustees?}

What does the portrait painted thus far show? To summarize briefly, the discussion so far has demonstrated that: (1) private foundations are nonoperating, grant-making, not-for-profit organizations, the funds of which are intended to serve the public welfare, (2) private foundations wield substantial influence through their investments and grants, (3) their financial clout is enhanced by special tax treatment that arguably could be characterized as a federal subsidy, (4) the typical board of trustees is a selfperpetuating entity, responsible to no external electorate in deter-

\footnotetext{
12 Peterson Comm'n Report, supra note 9, at 88.

${ }^{130}$ See, e.g., J. NASON, supra note 93 , at 69 . Some foundations have the additional problem of inefficiencies in staffing because of homogeneity. See note 114 supra and accompanying text.
} 
mining how the foundation's power is to be exercised, and (5) this co-optive selection process has led to a remarkable degree of homogeneity among trustees and to a great incidence of potential conflicts of interest.

Do these factors necessarily mean that some form of mandatory public input should be an essential element in the selection of the trustees of these foundations? Some, upon hearing a proposal of public control, might dismiss the proponent as a "doctrinaire populist."'131 Still, one hopes the following discussion will find a more receptive audience, open to both the suggestion that the governing system of private foundations is at variance with some of the most rudimentary principles of our society and the possibility that viable alternative systems of governance are available that do not conflict with these principles.

\section{A. Public Control of Institutions with Power to Order Society's Priorities}

The same concerns that have motivated students of corporate law to urge a greater degree of public control of corporations must have a similar impact on those who analyze foundations. The same lack of accountability that exists at the upper echelons of corporate management exists within the governing structure of foundations to an even greater degree because trustees of foundations are not, even in theory, responsible to an electorate composed of shareholders. Ralph Nader's characterizations of the corporate board, in his recently coauthored work calling for federal chartering of corporations, can be readily adapted and applied to foundations:

The modern corporation [foundation] is akin to a political state in which all powers are held by a single clique. The senior executives [trustees] of a large firm [foundation] are essentially not accountable to any other officials within the firm [or to those whom the entity is to serve-the beneficiaries]. ${ }^{132}$

Just as the accountability of corporations is a problem because of their substantial influence on society, so too must the lack of public control of foundations be a concern. Whether in terms of sheer amount of dollars or ultimate impact on society, significant private foundations wield sufficient influence to call for some form of direct societal control of their governance.

131 J. Nason, supra note 93 , at 35.

132 R. Nader, M. Green, \& J. Seligman, Tamma the Giant Corporation 118 (1976). 
Although neither the individual assets of significant private foundations nor their yearly expenditures rival the assets and expenditures of the largest American corporations, foundations exert as much influence in their arena as do corporations in their arena. Foundations are not involved in the manufacturing of goods; they deal with the production of ideas, scientific research, learning, health needs, and the arts. Foundations have no operative structure to maintain and are relatively free to allocate their resources as they deem fit. The impact of corporate expenditures will be seen in quality of products, working conditions, or environmental well-being. Each corporate activity constitutes an ordering of priorities that becomes an ordering of society's priorities; the same is true of large foundations with a pervasive impact on society. This ability of corporations to order society's priorities has led people such as Ralph Nader, ${ }^{133}$ Christopher Stone, ${ }^{134}$ Abram Chayes, ${ }^{135}$ and others to suggest the development of procedures that allow society to have greater control over corporate governance.

The difference in arenas does not lessen the ability of foundations to order society's priorities. The foundations' impact is felt in the decision to sponsor the development of a specific educational approach, a medium of entertainment, or an area of medical research, or to invest a portfolio in growth stocks instead of other more secure but less-income-producing securities. The repercussions of these activities are perhaps less dramatic than corporate activities because they are somewhat less visible, certainly less immediate, and probably more difficult to declare necessarily right or wrong for society. Nonetheless, these activities, like corporate activities, represent an ordering of priorities that ultimately becomes society's ordering. Collectively, this ordering involves the expenditure of billions of dollars. The decisions are made by private individuals chosen, not by the public, but by other private individuals. Therefore, while the influence exerted by foundations on society through grants and investments is not of the same nature as the influence of giant corporations, it is certainly of similar importance.

Sensitivity to the uncontrolled power of private foundations and the corresponding interest in placing foundations under public control is not a passing concern. It dates back at least to the beginning

iss See id.

i3 See C. Stone, Where the Law Ends: The Sochal Control of Corporate Behavior (1975).

35 See Chayes, The Modern Corporation and the Rule of Law, in ThE CoRPoration IN Modern Society 25 (E. Mason ed. 1960). 
of this century, when the large charitable foundations were first being formed to absorb the great wealth of the industrial magnates of the nineteenth and early twentieth centuries. When John D. Rockefeller sought a corporate charter from Congress in 1910 for the private foundation he sought to establish, he ran into stiff resistance. Congressional debate produced proposed restrictions that would have limited the assets of the foundation and the foundation's rights to accumulate income. The proposals also included a congressional option to terminate the proposed foundation's life after one hundred years. Most significant, the election of the foundation's trustees was to be subject to veto by a majority vote of a collected group of public and private officials that included the President of the United States, the Chief Justice of the Supreme Court, the President of the Senate, the Speaker of the House, and the presidents of five prestigious American umversities. ${ }^{136}$

Even with these restrictions, congressional resistance to the perpetuation of Rockefeller's wealth and influence was so great that he withdrew the application for federal incorporation and instead obtained a state charter in New York. ${ }^{137}$ The restrictions of the proposed federally incorporated foundation contained the rudiments of a selection process for trustees that would have involved an element of public input. ${ }^{138}$ Within half a decade, a selection committee very similar in nature to the one proposed for the Rockefeller Foundation was instituted in conjunction with the Cleveland Foundation, the nation's first community foundation. This committee, composed of both public and institutional officials, was not himited merely to disapproving the selections of others. It could select trustees for the foundation's committee in charge of distributions. ${ }^{139}$ Thus models exist that give society control over foundations' ability to order society's priorities.

\section{B. Public Determination of the Public Welfare}

Beyond arguments based upon concern with the wealth and influence of foundations, a more basic reason exists for suggesting the need for public input into the selection of the foundation's government. All significant private foundations have as their ultimate goal a desire to benefit the public. The foundation holds its funds in trust

\footnotetext{
i36 See W. NizLsEN, supra note 47 , at 51.

17 Id. at 52.

138 See id. at 51.

tw See Sugarman, supra note 22, at 1689-90.
} 
for the welfare of the public, and our society takes as axiomatic that the public can best determine what will be of public benefit. A primordial tenet of our society and our government is faith in the ability of citizens to regulate their own welfare and not to have it regulated for them. Such a tenet would not lead to the conclusion that foundations must be administered by the government but rather that the public must have an input in their governance. The pluralism offered to society by activities of foundations need not be sacrificed in accommodating the goal of input by the public. Providing the public with a role in selecting governors of foundations will not subject those foundations to the yoke of government influence. Indeed, it might well serve to legitimize their independence. ${ }^{140}$ Foundations can speak with a voice that responds to public needs, as determined by the public, while still inaintaining a distinctly nongovernmental outlook. ${ }^{11}$

\section{Public Administration of Public Funds}

Many erroneously regard funds of foundations as private funds and feel that the donor of these funds should be able to determine who will adininister thein by using a self-perpetuating private board. The assertion that donors or their appointees should have a perpetual and decisive influence on who governs the foundations is syinptomatic of an overall philosophy of foundations that regards the foundation's assets as private funds still within the domain of the donor's estate. ${ }^{142}$ When the late J. Howard Pew, then senior member of the Pew family, was asked why the Pew Memorial Trust never issued any report to the public (it remains today probably the most secretive of any siguificant private foundation), he shouted: "I'm not telling anybody anything. It's my money, isn't it?"'143

Regarding funds placed in trust for the public as private funds decades after initial donation is inconceivable for two reasons. ${ }^{144}$ First, foundation assets have been committed to public consumption, and the public should have a voice in determining how they will be consumed. One reasonably could question whether the Rockefeller brothers have greater justification than the public to

\footnotetext{
1to See pp. 819-20 infra.

${ }^{14}$ See pp. 821-32 infra.

${ }^{112}$ For further discussion of those who criticize external imposition of responsiveness to the public, see pp. 829-32 infra.

${ }^{143}$ W. NIELSEN, supra note 47, at 126.

i4 See generally note 16 supra.
} 
decide the ultimate disposition of the assets of the Rockefeller Brothers Fund thirty-seven years after dedication of the initial assets to the public benefit. ${ }^{145}$ Unfortunately, even in those imstances in which the control of the original donor has lapsed, as has apparently happened with the Ford Foundation, ${ }^{146}$ the self-selecting process for trustees still bars the public from input into the governance of foundations.

Second, a significant portion of the assets administered and ultimately distributed by foundations are in their hands rather than in the federal treasury's coffers because of the favorable tax treatment accorded foundations. ${ }^{117}$ Through charitable deductions and exemptions from income tax, foundations have been able to amass funds greatly in excess of the amount that would have been available if no deduction for charitable giving existed or if foundations had to pay taxes on their earnings comparable to the taxes paid by corporations or trusts. To the extent that a federal subsidy has existed, trustees are administering funds of a public nature that exceed the original funds of the donor plus earnings. ${ }^{148}$ This is another reason why foundations' funds should be managed by trustees as to whose selection the public has had its say.

\section{Internal Administrative Efficiencies}

Guaranteeing that foundations governed by publicly selected trustees will operate more efficiently or more creatively or more productively than foundations managed by self-selected boards may be impossible. To begin with, these values are probably incapable of measurement. ${ }^{149}$ Moreover, advocates on both sides argne the advantages of their preferred form of governance in terms of internal efficiencies of operation.

Observations made earlier, ${ }^{150}$ however, if they do not demonstrate a number of internal efficiencies that would arise from public selec-

is See generally text accompanying note 126 supra.

is See generally Weymouth, supra note 31, at 22, col. 1 .

it See pp. 795-802 supra.

us Charitable deductions for contributions to private foundations constitute an exception to the general rule in taxation that "no deduction is permitted for a contribution until the donor separates himself from the ownership of the assets donated." J. TRAUB, supra note 29 , at 192.

1" See J. NAson, supra note 93, at 32. After stating that "[n]o study along these lines has as yet been undertaken," the author then goes on to place the burden of proof with the critics of the present system. Id.

tse See pp. 806-07, 812 supra. 
tion of trustees, strongly suggest them. Both the understaffed foundation and the foundation controlled by its staff are malfunctions that would be less hikely to occur with public selection of trustees. The trustees' obligation to enhance the public welfare would be made more apparent in a system where the public selects those trustees. Fulfillment of that obligation requires adequate staffing for development of programs, allocation of grants, and investment and also requires the preservation of lines of managerial authority running from the trustee to the staff. ${ }^{151}$

Even assuming that a foundation governed by a publicly selected board would operate neither more nor less efficiently than one managed by a self-selected board, external benefits associated with a publicly selected board tip the balance in favor of such a governing structure. Basic societal values dictate that the public must have a role in determining what the needs of society are and what the priorities should be for satisfying those needs. The very act of allowing society a role in deciding how funds committed to society's benefit will be spent in itself provides an external good to society that transcends the question of which form of government is most efficient or creative. That external benefit is the fulfillment of society's need to be in control of its own welfare. That benefit thrusts on the proponents of the co-optive system the burden of demonstrat-

${ }^{131}$ One could find more cause for reticence in calling for a restructuring if one could demonstrate that the efficiency of the present system might be sacrificed in tbe process. An examination of the record, however, does not counsel such reticence. First, as previously noted, see text accompanying notes 117-18 supra, the perpetuation of the donor's control has caused many significant foundations to follow an imprudent policy of investment, which in turn results in a lack of diversity in portfolio holdings. Second, only a small proportion of the very largest foundations have developed the kind of administrative staff essential to the wise and beneficial distribution of millions of dollars in grants. See note 114 supra and accompanying text. Third, under the present governing structure, a minimal amount of direction filters down from the trustees, who have been designated to champion the public welfare, to the staff, who are supposed to put the foundation's programs into operation. See notes 129-30 supra and accompanying text. Fourth, foundations typically have achieved a quite unimpressive investment record. The Peterson Commission in 1970 concluded "that the investment performance of foundations is below par, and perhaps significantly so." PETERSON COMM'N REPORT, supra note 9 , at 75 . The Commission empbasized that society as a whole is being shortchanged by this "lackluster managenıent," which necessarily works to limit funds available to potential grantees by hundreds of millions of dollars annually. Id. Fiftb, foundations even appear to be lax in their efforts to determine the effectiveness of their grants. Forty-one percent of all foundations have no follow-up program to analyze how tbeir awards are being utilized, altbough $72 \%$ do require some form of reporting concerning past performance for further installment payments of grants. Id. at 91 . An astounding $91 \%$ of all foundations require no auditing of expenditures by grantees. Id. In light of the foregoing, any argument against tinkering with the present governing structure of foundations to preserve the administrative benefits of that system would be untenable. 
ing the superiority of their form of government. ${ }^{152}$

Another external benefit would accrue from the effect of the public on the composition of boards. Public influence on the process of selecting trustees undoubtedly would lead to a greater diversification of boards, which presently suffer from a high degree of homogeneity. As previously noted, ${ }^{153}$ the need for eliminating this sameness of personality has been a basic conclusion of virtually every study of foundations conducted within the last decade. Including the public in the selection process is the most direct means of accomplishing this end.

\section{E. The Legitimizing Function of Public Input}

The least controversial argument in support of public selection of trustees is the legitimizing function served by involving the public in governance of foundations. A recurring theme in much of the literature is the breadth and frequency of the attacks on foundations' policies. Foundations have been accused alternatively of being too radical and not radical enough and have been the subject of several major critical congressional hearings since World War II. ${ }^{154}$ Charitable nonprofit institutions as a whole incur an attitude ranging from skepticism to hostility among three important segments of American society. Blue collar workers, the "underclass for whom George Wallace has great appeal," and activists in political and environmental fields all possess varying degrees of resentment for the private nonprofit sector due to their aversion for elitism, their sense of exclusion from participation in governing foundations, their perception of the "ruling elite's disdain" for them, and their sense that foundations are unresponsive to their needs. ${ }^{155}$ Additionally, many educated and politically minded individuals view the nonprofit sector as "a denial of their notions of equity, democratic participation, and accountability." 156

The fears of and resentment toward what are viewed as powerful

152 But see note 149 supra.

iss See note 113 supra and accompanying text.

is E.g., Hearings on the Role of Private Foundations in Today's Society and a Review of the Impact of Charitable Provisions of the Tax Reform Act of 1969 on the Support and Operation of Private Foundations Before the Subcomm. on Foundations of the Senate Comm. on Finance, 93d Cong., 1st Sess. (1973); Tax Reform 1969: Hearings Before the House Comm. on Ways and Means (pt. 1), 91st Cong., 1st Sess. (1969).

iss Levy \& Nielsen, An Agenda For The Future, in 2 Regkarch Papkrs, supra note 4, at 1029, 1056-57.

15t Id. at 1057. 
elitists could be dissipated by a governing structure that provided for the public's inclusion in selecting trustees. Giving the public its say need not lead to less innovation or less undertaking of enterprises. Once the role of publicly selected trustees is defined, they would be as capable of making the same commitments toward expanding the horizons in education, arts, health, science, and national and international political studies as are self-selected trustees. In addition, because such trustees would not be chosen in a process that excluded the public, they would not have to struggle to overcome public hostility toward elitism and would be ensured a greater degree of acceptability.

\section{Alternative Models for Governing Foundations}

A final reason for including the public in the process of selecting trustees is the ready availability of alternative models for governance that do involve active public participation, some of which have already been adopted successfully by various foundations.

\section{A. Limitations on the Foundation's Life}

One approach to eliminating the self-perpetuating character of boards is to limit the length of a foundation's life or to terminate a foundation's tax-exempt status at the end of a specified number of years. A number of donors have created private foundations with stipulations that their life be limited to a specified number of years. Concerned with the dangers posed by a foundation with an indefinite existence, Julius Rosenwald established the Julius Rosenwald Fund with the direction that all the income and principal of the Fund be expended within twenty-five years of the death of the founder. . $^{157}$

The concept of limiting a foundation's life to combat selfperpetuating power has attracted some congressional interest as well. The Senate Committee on Finance passed an amendment to the 1969 Tax Reform Act that would have placed a forty year limit on the period of tax exemption of any private foundation. ${ }^{158}$ By that time, the foundation was to have distributed all its assets or to have

${ }^{157}$ See F. ANDrews, supra note 15, at 55-56. Two other ways to limit a foundation's life are to set a specific date for termination or to have it end within a certain period after incorporation. See id. at 103-04.

158 See S. ReP. No. 552, 91st Cong., 1st Sess. 25-26, reprinted in [1969] U.S. CodE Cong. \& AD. NEws 2027, 2052-53. 
become a public charity. ${ }^{159}$ If the foundation had made neither the distribution nor the conversion, it was to be taxed as a corporation or a trust, depending upon its status. The Finance Committee's amendment was aimed at curbing perpetual influence by the donor, an important theme in the proposals that the Treasury Department presented to Congress when the legislators first began their deliberations on the Tax Reform Act of $1969 .{ }^{160}$ One proposal recommended that donors and related persons be limited to twenty-five percent representation on any board after the first twenty-five years of the foundation's life. ${ }^{161}$ The Finance Committee's amendment, clearly going beyond the original Treasury proposals, was ultimately defeated by what one journalist described as "[a]ggressive foundation lobbying." ${ }^{162}$ But the problem to which this proposal addressed itself remained.

Self-terminating foundations and legislative proposals to limit the lives of foundations are responses to the problem of the selfperpetuating influence of foundations. Those approaches, however, may go too far. Terminating a foundation's life after a predetermined number of years effectively denies society whatever benefits experience can bring to managing foundations. A preordained termination negates the benefits of a developed and experienced staff, of tested and perhaps revised program goals, and of expertise in investment. Solutions to the problems of foundations should attempt to excise the disadvantages of the present governing structures without removing the advantages gained through maturity and experience. For termination to be a sensible solution to selfperpetuation, less drastic methods of confronting the problem would have to be unavailable. Alternatives, however, do exist that allow for public input into the selection of trustees, eliminating the undesirable factor of self-perpetuation but permitting foundations and society to benefit from experience.

\section{B. Three Models of Public Input}

1. Public Officials Selected in Other Capacities Serving as Trustees of Foundations

One model for public selection of trustees would consist of tapping the benefits of an already existing system of selection of representa-

13" For an understanding of the term "public charity," see note 23 supra.

iso See generally notes 1-11 supra and accompanying text.

i' See JoInt Comm. REPort, supra note 1, at 305.

162 C. WBLLES, supra note 117 , at 55. 
tives by the public. Such a model would require that trustees of foundations come from the ranks of publicly elected and, perhaps, appointed officials. The governing documents of significant private foundations could indicate which positions would be drawn upon to provide public representation on the foundation's board. Officials representing all segments of the electorate, from high-level administrative officials of national, state, and local governments, to public service administrators and school board officers, could be potential trustees. Obviously, the size and intended impact of the foundation would have a bearing on the level of the officials that might be designated. Thus foundations with a regional impact might limit themselves to officials chosen in state or countywide elections. Once the administrative, judicial, legislative, or other body from which the appointee is to come determined that the designation was acceptable, then the official duties arising from the designated pubic position would be understood to include serving as a trustee on the board of the specified foundation. To a certain extent, public approval of the officials' potential or past performance as trustees would be reflected in their initial selection to and retention in office. Most important, the foundation would be managed by persons selected by the public for their abilitites in and commitment to serving the public.

Officials connected with publicly supported institutions, including public universities and hospitals, might also be acceptable candidates for trusteeships. The public's role in selecting these institutional officials, however, might be more tenuous than its role in selecting normal representatives. Further, these officials, as representatives of institutions that might well be recipients of foundations' grants, would introduce an otherwise absent element of conflict of interest to the foundation's board. This problem could largely be avoided by designing appropriate procedures to disqualify trustees from voting on particular issues in which they have an interest.

A governing model incorporating officials elected in other capacities to serve as trustees, while attractive in terms of providing direct input by the public in selection of trustees, admittedly suffers from some impracticalities in other regards, making it the least attractive alternative. Initially, it opens up a range of conflicts for the officials who must wear two hats and who at times may be caught between competing policy goals. Conflicts might develop over how time is to be allocated between the two positions. A legitimate concern might arise as to potential politicizing of the board of trustees, which could 
result in party affiliations or political stances becoming the bases of decisions by the foundation's management.

While these impracticalities detract from the desirability of this model, they seem no more severe than those arising from the conflicts that presently exist in both government and foundations. Currently, many public officials successfully perform two roles in serving specific community interests while still functioning as governmental officials. Furthermore, few trustees today work solely as trustees. One easily can find conflicts of allegiance and roles among the investment bankers, corporate officers, lawyers, and even academics who serve on today's boards. ${ }^{163}$ On balance, these factors, coupled with the positive benefits of public selection, militate for this model instead of the present system.

\section{Selection of Trustees by Public Officials}

A variation of the first model, and one that has been proven successful if judged by its continued and frequent application, is a selection process in which public officials, rather than serving as trustees, select the trustees. This model has the advantage of removing some of the potential conflicts in roles and time obligations presented by the first model. Furthermore, it allows public officials to select trustees who might have particular expertise that would be attractive for foundations, such as a sophisticated knowledge of investments, familiarity with the needs of charities, a background in science or education, experience in the arts, or similar credentials. ${ }^{104}$ At the same time, the actual trustee is removed one step further from involvement in the political arena, thus minimizing the likelihood of politicization of the board. While the public would be selecting the selectors instead of the trustees, this procedure has been a traditionally acceptable mode of public control over government in our society. The public official making the selection will be held responsible for his choice by the electorate just as he is for other exercises of his official authority, but he need not be held responsible for each specific act of discretion of his appointee. As a result, this alternative provides public accountability for selection of trustees without transforming each decision of the foundation into a political issue.

is See text accompanying notes 115-18 supra.

Is This expertise also would help solve the problem of control by the staff. See generally notes $129-30$ supra and accompanying text. 
This model has heen applied with particular frequency to community foundations. The first community foundation came into existence in 1914 with the goal of eliminating the "dead-hand control" of the donor. ${ }^{165}$ Whereas the investment decisions of the community foundation do not have any public input because the funds typically are managed by the trust department of a bank, the allocation of grants is made by a distribution committee primarily selected by a group of public and institutional figures representative of the community that the foundation is intended to serve. Community foundations have found that "public confidence can be obtained by structures that provide for a broader participation or representation in the apparatus of the community foundation." $166 \mathrm{Com}$ munity foundations maintain programs of respectable size, distributing in $1973 \$ 60,000,000$ in grants and maintaining assets of $\$ 1,150,000,000 .{ }^{167}$ Community foundations, like private foundations, actively develop programs and establish goals rather than serve solely as funding sources to be tapped by charities. Their distribution committees, selected by public officials, operate as innovatively and as adventurously as the co-optively selected boards of private foundations, as is illustrated by the various broad programs of social research funded by community foundations. ${ }^{188}$ Viewed separately or in the aggregate, these programs are virtually indistinguishable from programs generated by private foundations.

Other foundations, including a number of governmental organizations, have operated effectively with public officials selecting their trustees. Although these foundations are not entirely analogous to private foundations, being actual government agencies and operating out of an annual budget of government funds rather than an endowment, they deal with the same questions in allocating grants as private foundations. For instance, the National Science Foundation, established in 1950 by an Act of Congress ${ }^{169}$ with the purpose of initiating and supporting research in the physical and other sciences, has its policies set by a board of twenty-four members ap-

its See generally Sugarman, supra note 22.

int Id. at 1691.

in Id.

16x Some of the many examples include: the Cleveland Foundation's landmark study of the criminal justice system in Cleveland in the 1920's, the New Hampshire Charitable Fund's recently estahlished fund to assist in the preservation of open spaces, and the New Haven Foundation's help in planning, evaluating, and funding a corrective program to establish community-based residences for criminal offenders. See id. at 1698-99.

wo National Science Foundation Act of 1950, Pub. L. No. 81-507, 64 Stat. 149 (codified at 42 U.S.C. $\$ \$ 1861-1881$ (1976)). 
pointed by the President with the advice and consent of the Senate. ${ }^{170}$ The President is directed to appoint members who have distinguished records in several enumerated fields of science and to give consideration to nominees submitted by the National Academy of Sciences and four different associations of colleges and universities. ${ }^{111}$ This technique combines selection by public officials with identification of potential nominees by interest groups that could provide valuable advice.

A procedure similar to the one employed in selecting the governing board of the National Science Foundation also was established in 1965 for the National Endowment for the Arts and The National Endowment for the Humanities. ${ }^{172}$ Each endowment is governed by a chairman appointed by the President with the advice and consent of the Senate. ${ }^{173}$ These chairmen are in turn advised by councils also selected by the President. ${ }^{14}$ As with the National Science Foundation, the purpose of the National Endowments for the Arts and Humanities is essentially identical to those of private foundations. Even though the two types of foundations are not entirely structurally analogous, private foundations could adopt the selection process of governmental foundations.

Actually, no need exists to look as far afield as community and governmental foundations to observe working models of a selection process utilizing public officials. The Trexler Foundation, a private foundation distributing the income from its $\$ 22,000,000$ portfolio locally for recreational and charitable purposes in Allentown, Pennsylvania and surrounding Lehigh County, ${ }^{175}$ is governed by a board of trustees selected solely by a public official. The last will and testament of Harry Trexler, executed in 1929, directed that vacancies in the original donor-appointed board of trustees would be filled by the Orphans' Court of Lehigh County. ${ }^{176}$ A degree of ultimate responsibility for operating the Trexler Foundation thus rests with a public official. The Northwest Area Foundation, which distrib-

170 42 U.S.C. $81863(a)$ (1976).

it Id. \& 1863(c).

12 National Foundation on the Arts and Humanities Act of 1965, Pub. L. No. 89-209, 79 Stat. 845 (codified at 20 U.S.C. $\$ \$ 951-960$ (1976)).

${ }^{173} 20$ U.S.C. $8 \S 954(\mathrm{~b})(1), 956(\mathrm{~b})(1)$ (1976).

in Id. $\$ \S 955(\mathrm{~b}), 957(\mathrm{~b})$.

17s See Trexler Foundation, Five Year Report 1971-1975 and 40 Year Review 1935-1975, at 11-29 (1975) (copy on file with the Virginia Law Review Association).

${ }^{176}$ Last Will and Testament of Harry C. Trexler I 12 (April 15, 1929) (copy on file with the Virginia Law Review Association). 
uted nearly $\$ 3,800,000$ in 1976 , similarly has its five trustees appointed by a state district court in Minnesota. ${ }^{177}$

The use of officials accountable to the public for selecting trustees is neither entirely foreign to private foundations nor demonstrably impractical. It offers a workable alternative to a selection process that otherwise guarantees the self-perpetuation of the influence of the imitial board, a lack of diversity, and exclusion of the public from the determination of its own self-interest.

\section{Selection of Trustees by Public Officials from a Prescreened Pool}

A limitation of the previous two models lies in their reliance on either the public official's qualifications to serve as a trustee or the public official's ability to select qualified trustees. Furthermore, the only influence given to those groups involved in and affected by the vitality of foundations-the staffs of foundations and donees-is their proportionate share of the public's influence. A third alternative, however, provides public input in the selection process while also assuring that qualified trustees will be selected and that affected interest groups could have special input. Under this alternative, public officials would select trustees from a prescreened pool. The composition of this pool would be determined by a national commission established by Congress to operate perpetually for the exclusive purpose of selecting candidates for trusteeships. The members of this commission would be selected by the President on a nonpartisan basis with the consent of Congress, much as the boards of governmental foundations are presently selected. ${ }^{178}$ The task of the national commission would be to select a pool of qualified potential trustees, and from this pool at a later stage predetermined public officials would make nonpartisan selections to fill the needs of various foundations. In essence, the plan would operate very similarly to the "Missouri Nonpartisan Court Plan" developed by the American Bar Association for selection of the judiciary. ${ }^{179}$ As an

in See F. ANDREws, supra note 15, at 46-47. Actually the trustees, selected by the court, in turn appoint directors who run the foundation-corporation.

${ }^{17 x}$ See notes 169-72 supra and accompanying text. The Filer Commission recommended the establishment of a national commission on the nonprofit sector to be appointed by a process that relied on the discretion of the President and his initial appointees. The purpose of this commission, however, was limited to serving us a type of permanent protector and observation body rather than determining candidates for trusteeships. See Frer Comm'N REPorT, supra note 4, at 191-93.

${ }^{173}$ See generally $R$. Watson \& R. Downing, The Polmitcs of the Bench and the Bar 13-14 (1969). 
optional arrangement, a specific portion of the pool could be selected from members of each of the previously mentioned interest groups to augment the representation of those intimately involved and immediately affected. When the actual selection is made, rough guidelines could be established to ensure that these interest groups, as well as the public in general, are represented on individual boards.

This third alternative has a triple value. It would provide for public input in selection of trustees, a high degree of expertise of the individual trustee, and optional representation of those operating or immediately affected by the foundation. It thus retains the benefits of the two previous models and eliminates the problems associated with limiting the foundation's life.

\section{Implementation of the Models}

If one of these three alternative inodels were implemented for private foundations, it could be phased in gradually by means of a five-year exemption. Such a provision allows the donor or his appointees to control the board of trustees during the first five years of the foundation's existence. This grace period serves two functions. First, it would placate partially those who view the co-optive system as a necessary incentive to encourage the wealthy to establish foundations. Second, it would provide the donor with an opportumity for inaugurating projects that later might be deemed worthy of continuation when the foundation is turned over to public control. A limited period of control by the donor would not entail the self-perpetuation of influence of the present co-optive system, yet it would allow donors the chance to set a good example and supply them with some sense of control over the destiny of their donations. ${ }^{180}$ In addition, control could come from the delineation of pur-

\footnotetext{
150 Theoretically, one might argue that as long as the publicly selected trustees enjoyed majority control of any board, no need would exist to eliminate entirely the influence of the donor or his appointees. Indeed, if it developed that donors' incentives were undermined severely by the eventual elimination of the donor and his appointees from the board, a compromise position allowing the donor to retain minority representation on the board could be formulated. As an initial proposition, however, the retention of any seats on the board by the donor would seem unattractive. Essentially, such retention would cut against the arguments developed above for public impact in the selection process. In split decisions among the publicly selected trustees, the donor's trustees would hold swing votes. In other instances, a donor's representatives might wield a disproportionate influence on the board, attributable to either an assumed superiority in being able to carry out the original purposes of the foundation or the deference that the other trustees show them because of their relation to the donor. One commentator has noted an analogous influence that the founder-donor exerts on
} 
pose in the documents creating the foundation.

To achieve this goal, governmental compulsion would not be necessary. The federal government would merely need to extend the existing "carrot" approach that it already uses to encourage "public" foundations. The present tax system favors foundations other than private, nonoperating foundations, such as community foundations, by providing that a higher percentage of a donor's contribution base will be deductible for donations made to "public" foundations rather than to private foundations. ${ }^{181}$ Furthermore, public foundations are not subject to the four percent excise tax on net investment income as are private foundations. ${ }^{182}$ The same justifications that permit encouraging the development of community foundations over private foundations through the tax code could be applied to a policy favoring the development of private foundations with publicly selected trustees over private foundations without such trustees. ${ }^{183}$ The differential in tax treatment between private foundations having publicly selected trustees and private foundations having co-optively selected trustees might need to be more marked than the differential in the present treatment of private and public foundations to assure that the desired outcome will be attained. ${ }^{184}$ The differential could be created through a combination of differences in the deductions allowable to donors and in the exemption from income taxation available to the foundations.

Not all private foundations need to be covered by this type of tax legislation. Certainly, smaller private foundations, of somewhere under $\$ 10,000,000$ of assets, would not present the same concern over their self-perpetuating influence because of their limited im-

trustees even after he disappears from the scene. That influence sometimes results in trustees abandoning their own responsibility, attempting instead to adhere to a policy or supposed policy of the donor. See A. ZURCHER, supra note 21, at 21,30. Thus, absent compelling circumstances, the risk of subjecting the publicly selected trustees to the potential influence of the donor-selected trustees outweighs any benefits associated with preserving representation of the donor on the board.

${ }_{1 \times 1}$ See note 82 supra and accompanying text.

$1 \times 2$ See I.R.C. $\$ 4940$.

$1 \times 3$ The Filer Commission has recommended the possible use of this "carrot" approach in encouraging "independent" foundations, the boards of which would be restricted to a minority representation of the donor, the donor's family, and the donor's associates. See Freer COMM'N REPORT, supra note 4, at 172-73. The Filer Commission's model of an "independent" foundation rejects public selection of trustees and merely requires limitations on representation of the donor.

ix Perhaps the present differential would be sufficient, for some indications can be found that the present tax treatment of public and private foundations has been a significant stimulus in the growth of community foundations since 1969. See Sugarman, supra note 22, at 1691. 
pact on society. Nationally, the aggregate number of foundations for which trustees would need to be selected runs no higher than 400 , necessitating a total of perhaps 1,700 trustees. ${ }^{185}$ Of course, only a small portion of these positions would need to be filled in any one year.

Moreover, the fact that many of the trustees of community foundations are selected in a manner involving public input suggests that the same approach should be feasible for selecting trustees for private foundations. Certainly enough qualified people can be found in the ranks of businessmen, academicians, former government officials, and the like to staff these foundations with competent and dedicated trustees chosen in a process including public input. Public selection of trustees should be accompanied by public meetings and public minutes of those meetings. To evaluate the performance of trustees, the frequently secretive procedures of foundations should be opened to the examination of the public. ${ }^{186}$

\section{The Counterarguments}

As stated earlier, ${ }^{187}$ those who study foundations generally recognize a need to broaden the representation of the boards of trustees. At the same time, one finds that attempts to broaden this representation by any external selection process meet resistance, ${ }^{188}$ which at times rises virtually to the level of a phobia. Consequently, the means often proposed for broadening representation by these "internal diversifiers" is the placement of limitations on the number of positions on the board that may be filled by the donor, the donor's family, or associates of the donor. ${ }^{189}$

iss Approximately 400 foundations have assets of $\$ 10,000,000$ or more, see Foundatron CENTER, supra note 6 , at xiii, and each private foundation has roughly 4.2 trustees, see $\mathrm{J}$. Nason, supra note 93 , at 4 n.5.

tst The Filer Commission has recommended that all grant-making organizations with annual grants of $\$ 100,000$ or more hold annual public meetings. See FiLER COMM'N REPORT, supra note 4 , at 166.

${ }^{2 \pi 7}$ See note 113 supra and accompanying text.

ixx For example, the Filer Commission's proposal for "independent" foundations provided broader representation by regulating the present selection process to limit control by the donor and the donor's family. It stopped short of actually allowing the public to determine its own preferences. See note 183 supra.

18s See, e.g., Stone, The Charitable Foundation: Its Governance, in 3 ResEARch Papers, supra note 4, at 1723, 1727-30. Professor Stone's thoughtfully developed proposals call for the elimination of controlling influence on the board by the donor within seven and one-half years and further reduction of that influence to under $20 \%$ representation within 15 years. See id. at 1729 . 
What are the fears with external control of the selection process? Basically, those opposing the concept of publicly selected trustees express a concern over the need to preserve our society's pluralism and the innovativeness of the private sector. Some believe that to allow the public to be involved in selection of trustees would eliminate the "other door" that fund-seekers have to knock on when turned down by government. Former Secretary of Health, Education, and Welfare Wilbur L. Cohen has stated:

[T] here are critical reasons for maintaining a vital balance of public and private support for human services, not the least of which is the continuing task of innovating in areas where public agencies lack knowledge or are afraid to venture. . . . The private sector is [especially] adept at innovation and at providing the models [that] government needs. ${ }^{190}$

Professor Stone propounds a very similar theme in urging the avoidance of governmental regulation of the selection of boards. $\mathrm{He}$ holds that the lack of diversity of foundation boards, "and especially the fact that foundation boards are not democratically representative, are not necessarily faults. Indeed, these characteristics may be virtues, since a foundation whose directors were chosen like legislators would present no real alternative to government support."'191

These opponents of the external selection of trustees assume that allowing public input will inevitably work to establish a mirrorimage of government. None of the three proposed models, however, would serve to duplicate any particular branch of government either in terms of the trustees selected or in the composition of their constituency. The two models that utilize public officials to select trustees would display no overlap between the personnel of government and foundation. The model utilizing a prescreened pool can be adapted effectively to provide representation to particular interest groups, which precise representation would have no counterpart in government. The model that recruits public officials to serve as trustees would exhibit overlap, but it would occur by chance, recreating no specific branch of government.

Assuming that the constituency selecting trustees is identical to the one electing governmental officials, this similarity of constituencies should not result in governing structures that mirror each other,

130 Cohen, Some Aspects of Evolving Social Policy in Relation to Private Philanthropy, in 2 RESEArtch PAPERS, supra note 4, at 657, 660, quoted in FIler Comm'N Report, supra note 4, at $\mathbf{4 2}$ (bracketed material in original but not in reprinted version).

II' Stone, supra note 189 , at 1730. 
especially where the governing bodies are intended to fulfill substantially different roles in our society. The fact that school boards and other local governmental entities are elected by the same populace does not imply that these bodies will possess identical outlooks. Officials of these bodies are selected with different criteria in mind, and their official obligations commit them to different policy approaches and positions. That same creativity and independence of mind, arguably an integral part of the present private system of selection, can just as readily be incorporated in the roles of publicly selected trustees. Public selection of trustees will not transform foundations into governmental agencies. Neither governmental funding nor governmental staffing will characterize foundations governed by publicly selected trustees.

Moreover, departure from a commitment to innovative approaches in serving the public welfare is unnecessary because such commitment would be the basis upon which the trustees would be selected. Their performance could be evaluated in terms of their innovation and initiative. Such a requirement of innovation and independence from government has been written into the descriptions of the jobs of numerous publicly selected officials, from consumer ombudsmen to officials of poverty programs to special prosecutors.

Excessive concern for any interference by government in foundations' lives was noted by the Donee Group in a report prepared in response to the Filer Commission's study. The Donee Group stated: "This fear [of intervention] of government pervades the [Filer Commission's] report . . . . [1]t is explicit in the refusal to accept a greater role for government in governance, access and accountability." 192 The inference that any intrusion of regulation by the government into the operations of foundations would result in a complete subversion of the value of foundations to society almost attains the stature of a "mythology"193 and is reflected in a general belief held by personnel of foundations in the inferiority of government programs. Certain private social welfare agencies have adopted "the convenient assumption that private sector programs intrinsically were superior to those of government-more innovative, less bureaucratic, more competently staffed."194

Corresponding prejudices are held by governmental agencies in

112 Donee Group, supra note 113, at 62.

13 See Levy \& Nielsen, supra note 155, at 1038.

in' Id. 
regard to agencies in the private sector. ${ }^{195}$ However strong the conviction may be, neither side's perceptions have been substantiated, and at present they remain no more than prejudices. Recognition of these myths is instructive when analyzing the private sector's assertion that a selection process regulated by the government would undermine the role presently played by private foundations in our society. Because no corroboration has been offered for that position, it is most likely a component of the mythology.

Finally, even if some degree of the pluralistic benefits that the present selection process offers society is indeed lost by public selection of trustees, this percentage necessarily would be quite small. The overall pluralistic nature of private foundations still would remain. Donors could continue to dictate the specific purposes to which the foundations' energies and funds are to be devoted in the documents establishing the foundations. Although public input would influence how those energies and funds are to be allocated within the delineated purposes of the foundation, the determination of the purpose of the foundation would remain with the donor.

\section{Conclusion}

Assuming that implementation of a system of public selection of trustees for private foundations involves no risk would be naive. In the final analysis, one must weigh the costs and benefits of any proposal. On the one side are the benefits to society of eliminating the restrictive effects of a self-perpetuating board while simultaneously providing society with a tool to determine how the power and influence of significant pools of wealth, established to serve the welfare of society, shall indeed serve that society. This must be balanced against whatever risks are inherent whenever an institution, to which we are accustomed, is modified. The risks presented by the three proposed selection models, however, are minimal in light of the magnitude of the problem. Given the purpose of foundations-benefitting the public-and the lack of responsibility to the public in their present organization, the ideals upon which our society rests require public input in the selection of trustees. 